\title{
EFFECT OF DIFFERENT SOURCES OF NITROGEN ON FLOWERING , YIELD AND FRUIT QUALITY OF SQUASH PLANTS.
}

\author{
Hassan, E. A.* ; M.A Hassan ${ }^{\star \star} ;$ O.F. Dakhly ${ }^{\star \star}$ and \\ Mona,N.Shehata ${ }^{* *}$ \\ 1. Central Laboratory of Organic Agric., Agric. Res. Center, Giza, Egypt \\ 2. Faculty of Agriculture, Minia University, Egypt.
}

\begin{abstract}
Field experiments were carried out at farm of Research Center of Agriculture, Mallawy, EL-Minia Governorate, Egypt, during the two successive Autumn seasons of 2003 and 2004 . Squash Cv. "Eskandrany" was selected to study the influence of chemical $\mathrm{N}$ rates . organic manure and biofertilizers on yield of squash. Treatments were arranged in split split - plot design in complete randomized block with four replicates. Chemical $\mathrm{N}$ rates $(0.0,30,45$ and $60 \mathrm{~kg} \mathrm{~N} /$ fed. ) treatment were arranged at random in the main plots .Three organic manure treatments (untreated, chicken manure and sheep manure) were distributed at random in the sub-plots, while three biofertilizer treatments (untreated, T26, T16 ) were distributed at random in sub-subplots. All flowers parameters significant affected by chemical $\mathrm{N}$ rates and biofertilizers. All interactions among the studied factors had significant effect on flower characters. All yield parameters were significantly affected by the chemical $\mathrm{N}$ rates in both seasons, where $45 \mathrm{Kg}$. N / fed. was obtained the highest value of early yield $(\mathrm{kg}) /$ plant, while there is no different between $60 \mathrm{~kg} \mathrm{~N} /$ fed. and $45 \mathrm{~kg} \mathrm{~N} /$ fed. on number of fruits ,average weight of fruit (g.) and total yield (ton/fed.). $\mathrm{NO}_{3}$ and $\mathrm{NO}_{2}$ concentrations were significantly affected by the chemical $\mathrm{N}$ rates in both seasons. $\mathrm{T} 26$ decreased $\mathrm{NO}_{3}$ and $\mathrm{NO}_{2}$ concentrations.
\end{abstract}

\section{INTRODUCTION}

In Egypt, squash (Cucurbita pepo L.) is one of the most important vegetable crops. The "Eskandrany" is the main cultivar of squash grown as a summer and autumn crop near cities where most of the crop is used for local consumption as well as for export. Squash fertilization have been investigated by Vennxi and Piazza (1975), who reported that raising nitrogen level from zero to $150 \mathrm{~kg}$./hect. increased total yield of squash fruits by $15 \%$. Many investigators studied male and female flowers of squash under chemical $\mathrm{N}$ fertilizer rates and /or biofertilizer such as Abd-El-Fattah and Sorial (2000); and on pumpkin by Feleafel et al. (2000). Inoculation with biofertilizer increased number of female flowers which agreed with that obtained on tomato by Barakat and Gabr (1998); and on squash by Abd-ElFattah and Sorial (2000). Increasing early yield with application of organic fertilizers are in agreement with that obtained on cucumber by Alphonse and Saad (2000a), and on melons by Segura (1999) also, on carrot by Wange, (1996);on sweet potato by Jadhav et al. (1998). Hassan et al. (2000) reported that the isolates under their studies had significantly improved the yield of squash more than the chemical fertilizer. Increasing $\mathrm{NO}_{3}$ concentrations with increasing $\mathrm{N}$-fertilizer rates agreed with that obtained on some vegetables as reported by Maynared et al. (1976); Gardner and Pew (1979); and on potato 
by Willumsen (1984), and disagreed with Steenhuizen (1986), and BlomZandstra (1989); and Mazur (1992) on squash. Gardner and Pew (1979) suggested that the slower nitrification rate with the sources containing $\mathrm{NH}_{4}-\mathrm{N}$ was considered to be the cause for the initially lower $\mathrm{NO}_{3}-\mathrm{N}$ level, Gobal (1980) pointed out that the lowest values of $\mathrm{NO}_{3}-\mathrm{N}$ in plants supplied with $\mathrm{NH}_{4}-\mathrm{N}$ sources may be due to $\mathrm{NH}_{4}$ which is used directly in $\mathrm{N}$ - assimilation in plant tissues, however, $\mathrm{NO}_{3}$ must be reduced at first to $\mathrm{NH}_{4}$ by nitrate reductase enzymes in plants.

\section{MATERIALS AND METHODS}

This investigation was carried out at farm of Research Center of Agriculture, Mallawy, EL-Minia Governorate, Egypt, The experiments were conducted during the two successive autumn seasons of 2003 and 2004. The purpose of this study was to investigate the effects of chemical-N, organic or / and bio- fertilizers on flowering, yield and yield components of squash "Cucurbita pepo L.", cultivar "Eskandrany". Soil samples were randomly taken from the experimental field before planting at depth $0-30 \mathrm{~cm}$. The mechanical and chemical analysis of the soil according to Page (1982) are presented in Table (1).

Table (1): Means of the mechanical and chemical analysis of the soil before squash planting in the autumn seasons of 2003 and 2004.

\begin{tabular}{|l|c|c|c|c|c|c|c|c|c|}
\hline \multirow{2}{*}{$\begin{array}{l}\text { Soil } \\
\text { Constituents }\end{array}$} & Sand & Silt & Clay & $\begin{array}{c}\text { texture } \\
\text { grade }\end{array}$ & $\begin{array}{c}\text { E.C* } \\
\text { m.mhos } \\
/ \mathbf{c m}\end{array}$ & $\begin{array}{c}\text { Organic } \\
\text { matter \% }\end{array}$ & $\begin{array}{c}\text { Available } \\
\mathbf{N} \%\end{array}$ & $\begin{array}{c}\text { Available } \\
\text { P. (ppm) }\end{array}$ & $\begin{array}{c}\text { Available } \\
\text { K..mg/ } \\
\mathbf{1 0 0 g} . \\
\text { soil }\end{array}$ \\
\hline $\begin{array}{l}\text { First } \\
\text { Season }\end{array}$ & 13.75 & 46.14 & 40.11 & Silt clay & 0.60 & 1.33 & 0.08 & 8.00 & 0.64 \\
\hline $\begin{array}{l}\text { Second } \\
\text { season }\end{array}$ & 13.76 & 46.12 & 40.12 & Silt clay & 0.71 & 2.01 & 0.12 & 20.00 & 1.12 \\
\hline
\end{tabular}

*E.C., = Electric conductivity.

The experimental field was ploughed and pulverized. Then, the soil was ridged into rows one-meter width and divided to plots. Each plot consisted of four rows, each row $3.5 \mathrm{~m}$ long and the plot area was $4.0 \times 1.0 \mathrm{x}$ $3.5=14 \mathrm{~m} 2$ (1/300 fed.,) seeds were sown on Sept. 9th in the two seasons on one side of the rows in hills $40 \mathrm{~cm}$ apart within the row. After germination, plants were thinned leaving two plants per hill.

Treatments were consisted of three factors i.e.; chemical-N, organic manure or / and bio-fertilizers and conducted using split-split plots system in a randomized complete block design with four replicates. The main plots were allocated for chemical $\mathrm{N}$-fertilizer rates. The sub- plots were devoted for the organic manure source. The sub-sub-plots were occupied by bio-fertilizer sources. The treatments were applied as follows:

1- Chemical N-fertilizer: -

Four nitrogen fertilizer levels were used i.e.; $0.0,30,45$ and $60 \mathrm{~kg} \mathrm{~N} /$ fed., in the form of ammonium nitrate (NH4NO3 - $33.5 \% \mathrm{~N}$ ). Each $\mathrm{N}$-level 
was divided to three equal doses, and applied during field preparation, after 20 and 40 days from sowing.

\section{2- Organic manure:-}

Three treatments were used: -

a - Control ( without organic manure and donated ).

b- Chicken manure at the rate of 7.5 ton / fed., and donated.

c- Sheep manure at the rate of 7.5 ton / fed., and donated.

Organic manures were added 30 days before planting at depth of 30 $\mathrm{cm}$ and covered with soil. At the meantime, the soil was irrigated. The chemical analysis of the chicken and sheep manures is presented in Table (2).

Table ( 2 ): The chemical analysis of the chicken and sheep manures applied in 2003 and 2004 autumn seasons .

\begin{tabular}{|l|c|c|c|c|}
\hline \multirow{2}{*}{ Chemical analysis } & \multicolumn{2}{|c|}{ Chicken manure } & \multicolumn{2}{c|}{ Sheep manure } \\
\cline { 2 - 5 } & $\begin{array}{c}\text { First } \\
\text { season }\end{array}$ & $\begin{array}{c}\text { Second } \\
\text { season }\end{array}$ & $\begin{array}{c}\text { First } \\
\text { season }\end{array}$ & $\begin{array}{c}\text { Second } \\
\text { season }\end{array}$ \\
\hline Total N \% & 2.90 & 3.40 & 1.85 & 2.02 \\
Total P \% & 0.84 & 1.01 & 0.62 & 0.74 \\
Total K \% & 2.12 & 2.31 & 2.25 & 2.00 \\
${ }^{\star}$ E.C. $(\mathrm{mmoh} / \mathrm{cm})$ & 7.40 & 7.63 & 15.0 & 10.30 \\
\hline
\end{tabular}

${ }^{*}$ E.C., = Electric conductivity.

\section{3- Bio- fertilizer: -}

Complete medium (CM) was used for Azotobacter vinelandii isolated in Genetics Department by Abdel-Rahem et al., (1995). The medium consisted of yeast extract $5.0 \mathrm{gm}$, pepton $5.0 \mathrm{gm}$, Nacl $5.0 \mathrm{gm}$, and agar 15 gm. (Strandberg and Wilson, 1968). Sterilization was carried out by autoclaving at $121 \mathrm{C}^{\circ}$ for $20 \mathrm{~min}$. the $\mathrm{pH}$ of the media was adjusted to 7.2 . Two strains of Aztobacter vinelandii, previosouly isolated, developed and their efficiency properties tested on their hosts (Dakhly and Abd- El-Mageed, 1997), were used in the present work. These strains were; Transforments Number 16 and 26. Inoculation was done after crude inoculum was preparated as reported by (Dakhly, 1993). The crude inoculation was diluted with irrigated water when used. Seeds were immersed in diluted inoculum for one hour before planting, and ample amounts of diluted inoculum was sprayed around the growing plants. The control was treated with a culture medium only.

All experimental plots were fertilized with $\mathrm{P}$ and $\mathrm{K}$ at the rate of $30 \mathrm{~kg}$ $\mathrm{P}_{2} \mathrm{O}_{5}$ / fed., in the form of triple superphosphate (45\% P2O5) and $48 \mathrm{~kg} \mathrm{~K}_{2} \mathrm{O}$ /fed. in the form of potassium sulphate $\left(48 \% \mathrm{~K}_{2} \mathrm{O}\right)$. P-fertilizer was applied once during soil preparation, whereas K-fertilizer was divided into two equal doses, one-half was applied during soil preparation and the other one-half after 20 days from sowing. The other common recommended culture practices for the commercial production of squash were carried out, wherever they were needed. 
Hassan, E. A. et al.

Data were recorded for the following parameters: -

A- Flowering characteristics: -

Five plants from each replicate were labeled for recording the following characters: -

- Number of days from sowing till the appearance of the first female flower

- Number of male flowers / plant.

- Number of female flowers / plant.

- Sex ratio was calculated according to the following equation: -

B- Yield and quality: -

No. of male flowers / plant

No. of female flowers/plant

- Early yield ( $\mathrm{kg} /$ plant). The sum of the yield of the first four pickings.

- Number of total fruits / plant.

- Average fruit weight (g.).

- Total yield (ton / fed.).

C- Chemical analysis of yields: -

$\mathrm{NO} 3$ and NO2-N concentrations in plants were measured by phenoldisulfonic acid method according to A. O. A. C. (1990).

Data were subjected to analysis of variance procedures and means were compared using L. S. D. test (according to Gomes and Gomes,1984).

\section{RESULTS AND DISCUSSION}

\section{1 - Flowering characteristics: -}

1-1- Number of days from sowing to the appearance of the first female flower: -

Data presented in Tables $(3,3 a, b \& c)$ show significant difference between the mean numbers of this character due to $\mathrm{N}$-chemical rates applied in both seasons. Among the different N-chemical rates, application of $45 \mathrm{~kg} \mathrm{~N}$ / fed., accelerated the appearance of the first female flower followed by $60 \mathrm{~kg}$ $\mathrm{N} /$ fed., Meanwhile, the organic manure source had significant effect on this character, in both seasons. Application of chicken manure showed the lowest number of days from sowing to the appearance of the first female flower. These results are quite similar with those obtained on cucumber by Alphonse and Saad (2000a). Also, the biofertilizer source showed significant effect. Application of T26 showed the lowest number of days from sowing to the appearance of the first female flower. Therefore, T26 seemed to be more effective on this character than T16. This should be reflected in the early yield.

The interactions between $A \times B, A \times C, B \times C$ and $A \times B \times C$ showed significant effect on this character, in both seasons. In general, application of $45 \mathrm{~kg} \mathrm{~N} /$ fed. $x$ chicken manure, $45 \mathrm{~kg} \mathrm{~N} /$ fed. $x$ T26, chicken manure $x$ T26 and $45 \mathrm{~kg} \mathrm{~N} /$ fed., $x$ chicken manure $\times$ T26 seemed to be the most promising treatments, in both seasons.

1-2- Number of male flowers / plant -

Data in Tables $(4,4 a, b \& c)$ indicated that number of male flowers / plant were significantly increased with application of chemical $\mathrm{N}$ rates, and 
organic manures whereas it decreased with application of biofertilizers, in both seasons. Among the various chemical $\mathrm{N}$ rates, application of $60 \mathrm{~kg} \mathrm{~N} /$ fed., showed the highest values and sheep manure surpassed chicken manure in this character, whereas T26 resulted in lower values as compared with T16. However, these values indicated that chemical $\mathrm{N}$-fertilizers showed the highest values followed by the organic manures, whereas biofertilizers showed the lowest values. Increasing number of male flower with increasing chemical $\mathrm{N}$ fertilizer rates agreed with that obtained on squash as reported by Abd-El-Fattah and Sorial (2000); and on cucumber by Feleafel (2000). Decreased number of male flowers with inoculation biofertilizer are in agreement with those obtained as reported by Abd-El-Fattah and Sorial (2000) on squash.

Table (3): Effects of $\mathbf{N}$ - chemical rates / fed., organic manure source or / and biofertilizer inoculums on number of days from sowing to the appearance of first female flower of squash plants during the two seasons.

\begin{tabular}{|c|c|c|c|c|c|c|c|c|c|c|c|c|}
\hline \multirow{5}{*}{$\begin{array}{l}\text { Organic } \\
\text { source } \\
\text { "B" }\end{array}$} & \multicolumn{12}{|c|}{ First season } \\
\hline & \multicolumn{11}{|c|}{ Chemical N- rates / fed. "A" } & \multirow{4}{*}{$\begin{array}{l}\text { Mean } \\
\text { "B" }\end{array}$} \\
\hline & & $0.0 \mathrm{~kg}$ & & $30.0 \mathrm{~kg}$ & & & $45.0 \mathrm{~kg}$ & & & $60.0 \mathrm{~kg}$ & & \\
\hline & \multicolumn{11}{|c|}{ Applied inoculate "C" } & \\
\hline & 0.0 & $T_{16}$ & 0.0 & $T_{16}$ & $T_{26}$ & 0.0 & $T_{16}$ & $T_{26}$ & 0.0 & $T_{16}$ & $T_{26}$ & \\
\hline 0.0 & 58.25 & \begin{tabular}{|l|l|}
47.75 & 43.00 \\
\end{tabular} & 58.25 & 47.75 & 43.00 & 41.00 & 39.00 & 35.00 & 39.75 & 41.25 & 39.00 & 42.17 \\
\hline Chic & 30.50 & \begin{tabular}{|l|l|}
30.50 & 29.50 \\
\end{tabular} & 30.50 & 30. & 29.50 & 31.50 & 29.00 & 28.00 & 30.75 & 29.00 & 31.00 & 30 \\
\hline Shee & 33.75 & 32.0028 .00 & 33.75 & 32.00 & 28.00 & 32.50 & 31.75 & 30.75 & 35.75 & 32.0 & 32.50 & 32.0 \\
\hline Mean"A" & & 37.03 & & 34.19 & & & 33.17 & & & & .56 & \\
\hline Mean"C" & \multicolumn{5}{|c|}{0.0 untreated $=36.39$} & \multicolumn{3}{|c|}{$T_{16}=34.89$} & \multicolumn{4}{|c|}{$T_{26}=3$} \\
\hline \multicolumn{13}{|c|}{ Second season } \\
\hline 0.0 & 59.50 & \begin{tabular}{|l|l|}
47.00 & 42.25 \\
\end{tabular} & 41.75 & 41.00 & 37.75 & 40.25 & 36.50 & 35.00 & 39.25 & 42.75 & 38.25 & 41.77 \\
\hline Chic & 30.00 & \begin{tabular}{|l|l|}
31.00 & 29.5 \\
\end{tabular} & 30.0 & 30 & 35.00 & 31.00 & 31.00 & 28.00 & 30.25 & 30.00 & 30.75 & 30.19 \\
\hline Shet & 32.75 & \begin{tabular}{|l|l|}
32.00 & 32.5 \\
\end{tabular} & 33.75 & 31.50 & 32.50 & 34.0 & 31.50 & 30.00 & 31.50 & 30.5 & 30.50 & 31.9 \\
\hline Mean "A & & 37.39 & & 34.33 & & & 33.03 & & & & .75 & \\
\hline Mean "C & 0 & reated & & & & $T_{16}=3$ & 34.63 & & & 08 & & \\
\hline
\end{tabular}

Table(3-a)the interaction between AxB Table(3-b)the interaction between AxC

\begin{tabular}{|c|c|c|c|c|c|c|c|c|c|}
\hline & \multirow{2}{*}{$\begin{array}{c}\text { Chemical } \\
\text { N-rate/ } \\
\text { fed., "A" }\end{array}$} & \multicolumn{3}{|c|}{$\begin{array}{c}\text { Organic manure source } \\
\text { "B " }\end{array}$} & & \multirow{2}{*}{$\begin{array}{c}\text { Chemical } \\
\text { N-rate/ } \\
\text { fed., "A" }\end{array}$} & \multicolumn{3}{|c|}{ Applied inoculate "C" } \\
\hline & & 0.0 & Chicken & Sheep & & & 0.0 & T16 & T26 \\
\hline \multirow{4}{*}{$\begin{array}{l}\text { First } \\
\text { season }\end{array}$} & 0 & 49.67 & & & \multirow{4}{*}{$\begin{array}{l}\text { First } \\
\text { season }\end{array}$} & 0.0 & 49.67 & 30.17 & 31.25 \\
\hline & $30 .($ & 40. & & & & & & & 31.83 \\
\hline & 45.0 & 38. & 2 & 31. & & 45 & 3 & 2 & 31.67 \\
\hline & 60.0 & 40.00 & 3 & 33. & & 60 & & & 33.42 \\
\hline \multirow{4}{*}{$\begin{array}{l}\text { Second } \\
\text { season }\end{array}$} & & & & & \multirow{4}{*}{$\begin{array}{l}\text { Second } \\
\text { season }\end{array}$} & & & & 34.75 \\
\hline & 30.0 & 40 & 5 & 32 & & 38 & 35 & 32 & 33.42 \\
\hline & 45.0 & 37.25 & 30.00 & 31. & & & 35.08 & 33.00 & 31.00 \\
\hline & 60.0 & 40.08 & 30.33 & 30.83 & & 60.0 & 33.67 & 34.42 & 33.17 \\
\hline
\end{tabular}


Hassan, E. A. et al.

Table $(3$ - c) the interaction between BxC

\begin{tabular}{|l|c|c|c|c|c|c|}
\hline \multirow{2}{*}{$\begin{array}{l}\text { Organic } \\
\text { manure source }\end{array}$} & \multicolumn{3}{|c|}{ First season } & \multicolumn{4}{c|}{ Second season } \\
\cline { 2 - 7 } “B” & $\mathbf{0 . 0}$ & T16 & T26 & $\mathbf{0 . 0}$ & T16 & T26 \\
\hline 0.0 & 45.25 & 42.50 & 38.75 & 45.19 & 41.81 & 38.31 \\
Chicken & 30.69 & 30.13 & 29.19 & 30.31 & 30.69 & 29.56 \\
Sheep & 33.25 & 32.06 & 30.81 & 33.00 & 31.38 & 31.38 \\
\hline
\end{tabular}

\begin{tabular}{|l|l|c|c|c|c|c|c|c|}
\hline & & A & B & C & AxB & AxC & BxC & AxBxC \\
\cline { 2 - 8 } L. S. D. at $5 \%$ & First season & 1.02 & 0.89 & 0.95 & 1.89 & 2.39 & 1.64 & 3.28 \\
\cline { 2 - 9 } & Second season & 1.20 & 0.90 & 1.12 & 1.80 & 2.25 & 1.60 & 3.13 \\
\hline
\end{tabular}

On the other hand, the interactions between $\mathrm{A} \times \mathrm{B}$, significantly increased number of male flowers / plant, in both seasons. The highest values were observed from the application of $60 \mathrm{~kg} \mathrm{~N} /$ fed., $\times 0.0$ organic manure and then decreased with the presence of organic manure. Chicken manure resulted in lower values than sheep manure. However, insignificant differences were obtained between the interactions of 30,45 or $60 \mathrm{~kg} \mathrm{~N}$ / fed., $x 0.0$ organic manure and those obtained from 30 or $4560 \mathrm{~kg} \times$ sheep manure, and $60 \mathrm{~kg} \mathrm{~N} /$ fed., $x$ chicken or sheep manures. Regarding the interactions between $\mathrm{A} \times \mathrm{C}$, significant increase in this character were obtained. Application of $60 \mathrm{~kg} \mathrm{~N} / \mathrm{fed}$., $\times 0.0$ biofertilizer showed the highest values. However, addition of biofertilizers to the chemical $\mathrm{N}$ had reduced this character and T26 showed to be more reduction than T16. Concerning the interaction between $\mathrm{B} \times \mathrm{C}$, significant reduction on number of male flowers / plant were obtained. The lowest significant values were obtained from biofertilizer in the absence of organic manures. Whereas, the highest values were obtained from sheep manure $\times 0.0$ biofertilizer. It should be mentioned that the values obtained from each single treatment surpassed those obtained from the interactions.

Table (4): Effects of $\mathbf{N}$ - chemical rates / fed., organic manure source or / and biofertilizer inoculums on number of male flower / plant of squash plants during the two autumn seasons.

\begin{tabular}{|c|c|c|c|c|c|c|c|c|c|c|c|c|c|}
\hline \multirow{5}{*}{$\begin{array}{l}\text { Organic } \\
\text { source } \\
\text { "B" }\end{array}$} & \multicolumn{13}{|c|}{ First season } \\
\hline & \multicolumn{12}{|c|}{ Chemical N- rates / fed. "A" } & \multirow{4}{*}{$\begin{array}{l}\text { Mean } \\
\text { "B" }\end{array}$} \\
\hline & \multicolumn{3}{|c|}{$0.0 \mathrm{~kg}$} & \multicolumn{3}{|c|}{$30.0 \mathrm{~kg}$} & \multicolumn{3}{|c|}{$45.0 \mathrm{~kg}$} & \multicolumn{3}{|c|}{$60.0 \mathrm{~kg}$} & \\
\hline & \multicolumn{12}{|c|}{ Applied inoculate "C" } & \\
\hline & 0.0 & $T_{16}$ & $T_{26}$ & 0.0 & $T_{16}$ & $\mathbf{T}_{26}$ & 0.0 & $T_{16}$ & $T_{26}$ & 0.0 & $T_{16}$ & $T_{26}$ & \\
\hline 0.0 & 15.8 & 15.1 & 14.4 & 26.7 & 25.8 & 25.5 & 26.8 & 25.9 & 25.1 & 26.9 & 25.7 & 25.5 & 23.274 \\
\hline Chicken & 21.2 & 20.3 & 19.1 & 25.2 & 24.1 & 24.6 & 25.7 & 25.1 & 24.5 & 25.9 & 25.3 & 24.2 & 23.764 \\
\hline Sheep & 22.4 & 21.4 & 21.3 & 25.4 & 25.2 & 24.9 & 6.2 & 25.6 & 25.0 & 26.3 & 25.9 & 25.3 & 24.581 \\
\hline Mean“A” & \multicolumn{3}{|c|}{19.004} & \multirow{2}{*}{\multicolumn{3}{|c|}{$\begin{array}{r}25.25 \\
d=24.544\end{array}$}} & \multicolumn{3}{|c|}{25.55} & \multicolumn{4}{|c|}{25.68} \\
\hline Mean"C" & \multicolumn{3}{|c|}{0.0 untreated $=24.544$} & & & & \multicolumn{3}{|c|}{$T_{16}=23.8$} & \multicolumn{4}{|c|}{$\mathrm{T}_{26}=23.275$} \\
\hline \multicolumn{14}{|c|}{ Second season } \\
\hline 0.0 & 16.3 & 15.7 & 14.8 & 27.0 & 26.3 & 25.6 & 27.3 & 26.5 & 25.7 & 27.4 & 26.6 & 26.0 & 23.754 \\
\hline Chicken & 22.8 & 21.1 & 20.9 & 25.3 & 24.8 & 24.2 & 25.4 & 24.8 & 24.3 & 26.1 & 25.1 & 25.4 & 24.079 \\
\hline Sheep & 22.9 & 21.9 & 20.6 & 26.2 & 25.9 & 25.1 & 26.3 & 26.0 & 25.2 & 26.4 & 26.2 & 25.2 & 24.82 \\
\hline Mean "A & \multicolumn{3}{|c|}{19.65} & \multirow{2}{*}{\multicolumn{3}{|c|}{$\begin{array}{r}25.58 \\
d-2494\end{array}$}} & \multicolumn{3}{|c|}{25.69} & \multicolumn{4}{|c|}{25.94} \\
\hline Mean "C & \multicolumn{3}{|c|}{0.0 untreated $=24.94$} & & & & \multicolumn{3}{|c|}{$\mathrm{T}_{16}=24.227$} & \multicolumn{4}{|c|}{$\mathrm{T}_{26}=23.486$} \\
\hline
\end{tabular}


Table (4-a) the interaction between AxB Table (4-b) the interaction between AxC

\begin{tabular}{|c|c|c|c|c|c|c|c|c|c|}
\hline & \multirow{2}{*}{$\begin{array}{c}\text { Chemical } \\
\text { N-rate// } \\
\text { fed., "A" }\end{array}$} & \multicolumn{3}{|c|}{$\begin{array}{l}\text { Organic manure source } \\
\text { " B" }\end{array}$} & & \multirow{2}{*}{$\begin{array}{c}\text { Chemical } \\
\text { N-rate/ } \\
\text { fed.. "A", }\end{array}$} & \multicolumn{3}{|c|}{ Applied inoculate "C" } \\
\hline & & 0.0 & Chicken & Sheep & & & 0.0 & T16 & T26 \\
\hline \multirow{4}{*}{$\begin{array}{l}\text { First } \\
\text { season }\end{array}$} & \begin{tabular}{|l|} 
\\
\end{tabular} & 15.1 & 20.2 & 217 & \multirow{4}{*}{$\begin{array}{l}\text { First } \\
\text { season }\end{array}$} & 0.0 & 19.8 & 18.9 & 18.3 \\
\hline & $30.6-(-2)-x-1$ & 25.9 & 24.6 & 25.2 & & 30.0 & 25.8 & 25.0 & 24.9 \\
\hline & 45.0 & 25.9 & 25.1 & 25.6 & & 45 & 26.2 & 25.6 & 24.8 \\
\hline & & 26 & & & & 6 & & 25 & 24.9 \\
\hline \multirow{4}{*}{$\begin{array}{l}\text { Second } \\
\text { season }\end{array}$} & 0 & 156 & 21.6 & 21 & \multirow{4}{*}{$\begin{array}{l}\text { Second } \\
\text { season }\end{array}$} & 0 & 19.0 & 21.5 & 19.0 \\
\hline & 30.0 & 26.3 & 24.7 & 25.7 & & 30.0 & 26.6 & 25.2 & 25.3 \\
\hline & 45.0 & 26.5 & 24.8 & 25.8 & & 45 & 26.8 & 25.8 & 26.2 \\
\hline & 60.0 & 26.7 & 25.2 & 25.9 & & 60.0 & 27.0 & 25.9 & 26.7 \\
\hline
\end{tabular}

Table (4 - c) the interaction between BxC

\begin{tabular}{|l|c|c|c|c|c|c|}
\hline \multirow{2}{*}{$\begin{array}{l}\text { Organic } \\
\text { manure }\end{array}$} & \multicolumn{6}{|c|}{ Applied inoculate "C " } \\
\cline { 2 - 7 } & \multicolumn{3}{|c|}{ First season } & \multicolumn{3}{c|}{ Second season } \\
\cline { 2 - 7 } & $\mathbf{0 . 0}$ & T16 & T26 & $\mathbf{0 . 0}$ & T16 & T26 \\
\hline Chicken & 24.1 & 23.1 & 22.6 & 20.7 & 19.5 & 18.8 \\
Sheep & 24.5 & 23.7 & 23.1 & 26.2 & 25.7 & 24.9 \\
\hline
\end{tabular}

\begin{tabular}{|l|l|c|c|c|c|c|c|c|}
\hline \multirow{2}{*}{$\begin{array}{l}\text { L. S. D. at } \\
5 \%\end{array}$} & & A & B & C & AxB & AxC & BxC & AxBxC \\
\cline { 2 - 9 } & First season & 0.75 & 0.58 & 0.80 & 1.16 & 1.61 & 1.61 & 2.79 \\
\cline { 2 - 9 } & Second season & 1.06 & 0.98 & 1.09 & 1.96 & 2.18 & 1.89 & 3.77 \\
\hline
\end{tabular}

In general, the interaction of the three factors, significantly affected this character, in both seasons. Among these interactions the highest values of number of male flower per plant were obtained from chemical $\mathrm{N}$ at $60 \mathrm{~kg} /$ fed., $\times 0.0$ organic manure $\times 0.0$ biofertilizer. Again, the triple interactions were more effective in reducing this character than that obtained from one or two sorts of fertilizers and higher $\mathrm{N}$-chemical rate alone showed to be the most effective in increasing number of male flowers per plant.

\section{1-3-Number of female flowers / plant: -}

Data in Tables $(5,5 a, b \& c)$ showed that number of female flowers per plant was significantly increased with application of chemical $\mathrm{N}$ rates, organic manures or biofertilizers, in both seasons. Within the various chemical $\mathrm{N}$ rates, application of $60 \mathrm{~kg} \mathrm{~N} /$ fed., showed the highest values, whereas chicken manure gave higher values than sheep manure in number of female flowers per plant and T26 resulted in higher values than T16. However, these values indicate that quite similar responses in this character due to these treatments were obtained. Increasing number of female flower with increasing chemical $\mathrm{N}$ fertilizer rates agreed with that obtained on squash as reported by Abd-El-Fattah and Sorial (2000); and on pumpkin by Feleafel (2000). Inoculation with biofertilizer increased number of female flowers which agreed with that obtained on tomato by Barakat and Gabr (1998); and on squash by Abd-El-Fattah and Sorial (2000). Regarding the interactions between $A \times B$, significant increase in number of female flowers per plant were obtained. The highest values were observed from the application of 60 $\mathrm{kg} \mathrm{N} /$ fed., $x$ chicken manure. The interactions between $A \times C$ resulted was significant increase in this character. Application of $60 \mathrm{~kg} \mathrm{~N} /$ fed., x T26 
Hassan, E. A. et al.

showed the highest value. These results are quite similar with those obtained on tomato by Barakat and Gabr (1998); and on squash by Abd-El-Fattah and Sorial (2000). Regarding the interactions between B x C, significant increase in number of female flowers per plant were gained, in both seasons. Number of female flowers per plant obtained from the interaction of chicken manure $x$ T26 showed the highest values.

Table (5): Effects of $\mathbf{N}$ - chemical rates / fed., organic manure source or / and biofertilizer inoculums on number of female flower / plant of squash plants during the two autumn seasons.

\begin{tabular}{|c|c|c|c|c|c|c|c|c|c|c|c|c|c|}
\hline \multirow{5}{*}{$\begin{array}{l}\text { Organic } \\
\text { source } \\
\text { "B"B” }\end{array}$} & \multicolumn{13}{|c|}{ First season } \\
\hline & \multicolumn{12}{|c|}{ Chemical N- rates / fed. "A" } & \multirow{4}{*}{$\begin{array}{l}\text { Mean } \\
\text { "B" }\end{array}$} \\
\hline & \multicolumn{3}{|c|}{$0.0 \mathrm{~kg}$} & \multicolumn{3}{|c|}{$30.0 \mathrm{~kg}$} & \multicolumn{3}{|c|}{$45.0 \mathrm{~kg}$} & \multicolumn{3}{|c|}{$60.0 \mathrm{~kg}$} & \\
\hline & \multicolumn{12}{|c|}{ Applied inoculate "C" } & \\
\hline & 0.0 & $\mathrm{~T}_{16}$ & $\mathrm{~T}_{26}$ & 0.0 & $\mathrm{~T}_{16}$ & $\mathrm{~T}_{26}$ & 0.0 & $T_{16}$ & $\mathrm{~T}_{26}$ & 0.0 & $T_{16}$ & $\mathrm{~T}_{26}$ & \\
\hline 0.0 & 8.9 & 9.7 & 9.9 & 18.4 & 19.5 & 19.6 & 20.3 & 20.3 & 21.1 & 21.2 & 21.9 & 22.2 & 17.76 \\
\hline Chicken & 14.5 & 15.8 & 16.7 & 20.0 & 20.8 & 22.2 & 22.4 & 22.5 & 22.7 & 23.1 & 23.3 & 23.5 & 20.604 \\
\hline Sheep & 15.0 & 15.1 & 16.5 & 18.1 & 19.8 & 19.9 & 20.3 & 20.7 & 21.6 & 21.1 & 21.2 & 22.4 & 19.313 \\
\hline Mean"A" & \multicolumn{3}{|c|}{13.576} & \multirow{2}{*}{\multicolumn{3}{|c|}{$\begin{array}{r}19.814 \\
d=18.617\end{array}$}} & \multicolumn{3}{|c|}{21.299} & \multicolumn{4}{|c|}{22.213} \\
\hline Mean“C” & \multicolumn{3}{|c|}{0.0 untreated $=18.617$} & & & & \multicolumn{3}{|c|}{$\mathrm{T}_{16}=19.21$} & \multicolumn{4}{|c|}{$\mathrm{T}_{26}=19.85$} \\
\hline \multicolumn{14}{|c|}{ Second season } \\
\hline 0.0 & 8.9 & 9.5 & 10.3 & 18.4 & 19.1 & 19.4 & 19.6 & 22.0 & 23.1 & 21.1 & 21.8 & 23.0 & 18.015 \\
\hline Chicken & 15.2 & 15.4 & 17.3 & 18.84 & 19.8 & 20.2 & 21.1 & 22.8 & 23.5 & 22.3 & 23.2 & 24. & 20.314 \\
\hline Sheep & 14.1 & 14.5 & 14.9 & 18.56 & 19.3 & 20.7 & 19.8 & 23.2 & 23.5 & 20.6 & 22.0 & 23.2 & 19.539 \\
\hline Mean "A & \multicolumn{3}{|c|}{13.334} & \multirow{2}{*}{\multicolumn{3}{|c|}{$\begin{array}{c}19.358 \\
d=18.209\end{array}$}} & \multirow{2}{*}{\multicolumn{3}{|c|}{$\begin{array}{c}22.079 \\
T_{16}=19.384\end{array}$}} & \multicolumn{4}{|c|}{22.38} \\
\hline Mean "C & \multicolumn{3}{|c|}{0.0 untreated $=18.209$} & & & & & & & \multicolumn{4}{|c|}{$T_{26}=20.275$} \\
\hline
\end{tabular}

\section{Table (5-a) the interaction between AxB Table (5-b) the interaction between AxC}

\begin{tabular}{|c|c|c|c|c|c|c|c|c|c|}
\hline & \multirow{2}{*}{$\begin{array}{c}\text { Chemical } \\
\text { N-rate/ } \\
\text { fed., "A" }\end{array}$} & \multicolumn{3}{|c|}{$\begin{array}{l}\text { Organic manure source } \\
\text { "B " }\end{array}$} & & \multirow{2}{*}{$\begin{array}{c}\text { Chemical } \\
\text { N-rate/ } \\
\text { fed., "A" }\end{array}$} & \multicolumn{3}{|c|}{ Applied inoculate "C" } \\
\hline & & 0.0 & Chicken & Sheep & & & 0.0 & T16 & T26 \\
\hline \multirow{4}{*}{$\begin{array}{l}\text { First } \\
\text { season }\end{array}$} & 0.0 & 9.5 & 15.7 & 15.6 & \multirow{4}{*}{$\begin{array}{l}\text { First } \\
\text { season }\end{array}$} & 0.0 & 12.8 & 13 & 14.4 \\
\hline & 30.0 & 19.2 & .0 & $1 \mathrm{~s}$ & & 30.0 & 18.9 & 20.1 & 20.5 \\
\hline & 45.0 & 20.6 & 2.5 & 20.8 & & 45.0 & 9 & 21.1 & 21.8 \\
\hline & 6( & 21.8 & & & & & & 22.2 & 22.7 \\
\hline Second & & & & & \multirow{4}{*}{$\mid \begin{array}{l}\text { Second } \\
\text { season }\end{array}$} & & & 17 & 14.2 \\
\hline \multirow[t]{3}{*}{ season } & 30.0 & 18.9 & 19.6 & 19 & & 30 & 18.6 & 19.4 & 20.1 \\
\hline & 45.0 & 21.6 & 22.5 & 22.2 & & 45.0 & 20.2 & 22.7 & 23.4 \\
\hline & 60.0 & 22.0 & 23.2 & 21.9 & & 60.0 & 21.3 & 22.3 & 23.5 \\
\hline
\end{tabular}

Table (5 - c) the interaction between BxC

\begin{tabular}{|c|c|c|c|c|c|c|c|c|c|}
\hline \multirow{3}{*}{$\begin{array}{l}\text { Organic } \\
\text { manure } \\
\text { source "B" }\end{array}$} & \multicolumn{9}{|c|}{ Applied inoculate "C" } \\
\hline & \multicolumn{4}{|c|}{ First season } & \multicolumn{5}{|c|}{ Second season } \\
\hline & 0.0 & T16 & & T26 & 0.0 & & & & 26 \\
\hline 0.0 & 17.2 & 17.9 & & 18.2 & 17.0 & & & & 0 \\
\hline Chicken & 20.0 & 20.6 & & 21.3 & 19.4 & & & & .3 \\
\hline Sheep & 18.6 & 19.2 & & 20.1 & 18.3 & & & & .6 \\
\hline \multirow{3}{*}{$\begin{array}{l}\text { L. S. D. at } \\
5 \%\end{array}$} & & & $\mathbf{A}$ & B & C & AxB & AxC & BxC & AxBxC \\
\hline & seaso & & 0.08 & 0.60 & 0.64 & 1.21 & 1.28 & 1.11 & 2.22 \\
\hline & ond sea & son & 1.37 & 0.68 & 0.77 & 1.37 & 1.54 & 1.33 & 2.66 \\
\hline
\end{tabular}

Concerning the interactions of the three factors, significant increase was obtained, in both seasons. Among these interactions, the highest values 
of number of female flowers per plant were obtained from chemical $\mathrm{N}$ at 60 $\mathrm{kg} \mathrm{N} /$ fed., $x$ chicken manure $x$ T26. Again, the triple interactions were more effective in this character than that obtained from one or two sorts of fertilizers.

1-4- Sex ratio: -

Data in Tables $(6,6 a, b \& c)$ indicated that sex ratio was significantly decreased with application of chemical $\mathrm{N}$ rates, organic manures and biofertilizers, in both seasons. Among the various chemical $\mathrm{N}$ rates, application of $60 \mathrm{~kg} \mathrm{~N} /$ fed., showed the lowest values, whereas chicken manure gave the lower values of sex ratio than sheep manure in this character and T26 reduced this character than T16. Increasing chemical N fertilizer rates decreased sex ratio, these results are in disagreement with that obtained on squash by Abd-El-Fattah and Sorial (2000). Inoculation with biofertilizers decreased sex ratio and agreed with that obtained on squash by Abd-El-Fattah and Sorial (2000).

In general, the interactions between $\mathrm{A} \times \mathrm{B}$, significantly decreased sex ratio in both seasons. The least values were observed from the application of $60 \mathrm{~kg} \mathrm{~N} /$ fed., $x$ chicken manure.

On the other hand, the interactions between $\mathrm{A} \times \mathrm{C}$, resulted in significant reduction in this character, in both seasons. Application of $60 \mathrm{~kg} \mathrm{~N}$ / fed., x T26 showed the values of. These results are in line with those obtained on squash by Abd-El-Fattah and Sorial (2000). Significant decrease was gained from the interaction between $B \times C$, in both seasons. Sex ratio from the interaction of chicken manure $\times$ T26 showed the lowest values. Concerning the interactions of $\mathrm{A} \times \mathrm{B} \times \mathrm{C}$ factors, significant effect was obtained, in both seasons. Among these interactions, the most reduction of sex ratio were obtained from chemical $\mathrm{N}$ at $60 \mathrm{~kg} \mathrm{~N} /$ fed., $\mathrm{x}$ chicken manure $\mathrm{x}$ T26.

\section{2 - Total yield and yield components : -}

\section{2 -1- Early yield (kg / plant): -}

Data in Tables $(7,7 a, b \& c)$ indicated that this character significantly responded positively to the chemical $\mathrm{N}$ fertilizer rates, organic manures or biofertilizers, in both seasons. Among the various chemical $\mathrm{N}$-rates application of $45 \mathrm{~kg} \mathrm{~N} /$ fed., showed the most significant increase in early yield / plant, whereas chicken manure surpassed sheep manure in this parameter meanwhile, T26 resulted in higher values than T16.

However, these values indicated that application of chemical $\mathrm{N}$-rate at $45 \mathrm{~kg} \mathrm{~N} /$ fed., showed highest value followed by chicken manure, whereas application of T26 resulted in the lowest value. The values obtained from chicken manure and that obtained from T26 were approximately equal to the values of early yield between 30 and $45 \mathrm{~kg}$ chemical $\mathrm{N}$ rate. Although, organic manure was more effective than biofertilizer on this parameter. Increasing early yield with increasing chemical $\mathrm{N}$ fertilizer rates agreed with that obtained on squash as reported by Wagih et al., (1986), and Abd-El-Fattah and Sorial (2000). Increasing early yield with application of organic fertilizers are in agreement with that obtained on cucumber by Alphonse and Saad (2000b) and on melons by Segura (1999). 
Hassan, E. A. et al.

Increasing early yield with inoculation of biofertilizer agreed with that obtained on squash Cv. "Eskandrany " by Abd-El-Fattah and Sorial (2000).

Regarding the interaction between $A \times B$, significant increase in early yield ( $\mathrm{kg} /$ plant) was obtained, in both seasons. The highest values were observed from the application of $45 \mathrm{~kg} \mathrm{~N} /$ fed., $\mathrm{x}$ chicken manure. Concerning the interaction between $\mathrm{A} \times \mathrm{C}$ significant increase in this character was obtained.

Table (6): Effects of $\mathbf{N}$ - chemical rates / fed., organic manure source or / and biofertilizer inoculums on sex ratio of squash plants during the two autumn seasons.

\begin{tabular}{|c|c|c|c|c|c|c|c|c|c|c|c|c|c|}
\hline \multirow{5}{*}{$\begin{array}{l}\text { Organic } \\
\text { source } \\
\text { "B" }\end{array}$} & \multicolumn{13}{|c|}{ First season } \\
\hline & \multicolumn{12}{|c|}{ Chemical N- rates / fed. "A" } & \multirow{4}{*}{$\begin{array}{c}\text { Mean } \\
\text { "B" }\end{array}$} \\
\hline & \multicolumn{3}{|c|}{$0.0 \mathrm{~kg}$} & \multicolumn{3}{|c|}{$30.0 \mathrm{~kg}$} & \multicolumn{3}{|c|}{$45.0 \mathrm{~kg}$} & \multicolumn{3}{|c|}{$60.0 \mathrm{~kg}$} & \\
\hline & \multicolumn{12}{|c|}{ Applied inoculate "C" } & \\
\hline & 0.0 & $T_{16}$ & $\mathbf{T}_{26}$ & 0.0 & $T_{16}$ & $T_{26}$ & 0.0 & $\mathbf{T}_{16}$ & $\mathbf{T}_{26}$ & 0.0 & $T_{16}$ & $T_{26}$ & \\
\hline 0.0 & 1.77 & 156 & 1.45 & 1.45 & 1.32 & 1.30 & 1.32 & 1.28 & 1.19 & 1.27 & 1.17 & 1.15 & 1.352 \\
\hline Chicken & 1.46 & 1.29 & 1.14 & 1.26 & 1.16 & 1.11 & 1.15 & 1.12 & 1.08 & 1.12 & 1.09 & 1.03 & 1.167 \\
\hline Sheep & 1.49 & 1.42 & 1.29 & 1.40 & 1.27 & 1.25 & 1.29 & 1.24 & 1.16 & 1.25 & 1.22 & 1.13 & 1.284 \\
\hline Mean“A” & & 1.43 & & & 1.28 & & \multicolumn{3}{|c|}{1.203} & \multicolumn{4}{|c|}{1.159} \\
\hline Mean“C” & \multicolumn{6}{|c|}{0.0 untreated $=1.353$} & & $16=1.2$ & & & $\mathrm{~T}_{26}=$ & 1.190 & \\
\hline \multicolumn{14}{|c|}{ Second season } \\
\hline 0.0 & 1.84 & 1.65 & 1.43 & 1.47 & 1.38 & 1.32 & 1.39 & 1.20 & 1.11 & 1.30 & 1.22 & 1.13 & 1.370 \\
\hline Chicken & 1.50 & 1.37 & 1.21 & 1.34 & 1.25 & 1.20 & 1.20 & 1.09 & 1.03 & 1.17 & 1.08 & 1.01 & 1.204 \\
\hline Sheep & 1.62 & 1.51 & 1.38 & 1.41 & 1.34 & 1.21 & 1.33 & 1.12 & 1.07 & 1.28 & 1.19 & 1.09 & 1.296 \\
\hline Mean "A & \multicolumn{3}{|c|}{1.501} & \multicolumn{3}{|c|}{1.324} & \multicolumn{3}{|c|}{1.171} & \multicolumn{4}{|c|}{1.163} \\
\hline Mean "C & \multicolumn{6}{|c|}{0.0 untreated $=1.404$} & \multicolumn{3}{|c|}{$\mathrm{T}_{16}=1.283$} & \multicolumn{4}{|c|}{$\mathrm{T}_{26}=1.185$} \\
\hline
\end{tabular}

Table (6-a) the interaction between AxB Table (6-b) the interaction between AxC

\begin{tabular}{|c|c|c|c|c|c|c|c|c|c|}
\hline & \multirow{2}{*}{$\begin{array}{c}\text { Chemical } \\
\text { N-rate/ } \\
\text { fed., "A" } \\
\end{array}$} & \multicolumn{3}{|c|}{$\begin{array}{c}\text { Organic manure source } \\
\text { " B " }\end{array}$} & & \multirow{2}{*}{$\begin{array}{c}\text { Chemical } \\
\text { N-rate/ } \\
\text { fed., "A" } \\
\end{array}$} & \multicolumn{3}{|c|}{ Applied inoculate " C" } \\
\hline & & 0.0 & Chicken & Sheep & & & 0.0 & T16 & T26 \\
\hline & 0.0 & 1.593 & 1.297 & 1.400 & & 0.0 & 1.573 & 1.423 & 1.293 \\
\hline First & 30.0 & 1.357 & 1.177 & 1.307 & Firs & 30.0 & 1.370 & 1.250 & 1.220 \\
\hline \multirow{2}{*}{ season } & 45.0 & 1.263 & 1.117 & 1.230 & \multirow[t]{2}{*}{ season } & 45.0 & 1.253 & 1.213 & 1.143 \\
\hline & 60.0 & 1.197 & 1.080 & 1.200 & & 60.0 & 1.213 & 1.160 & 1.103 \\
\hline Second & 0.0 & 1.640 & 1.360 & 1.503 & Second & 0.0 & 1.653 & 1.510 & 1.340 \\
\hline \multirow[t]{3}{*}{ season } & 30.0 & 1.390 & 1.263 & 1.320 & \multirow[t]{3}{*}{ season } & 30.0 & 1.407 & 1.323 & 1.243 \\
\hline & 45.0 & 1.233 & 1.107 & 1.173 & & 45.0 & 1.307 & 1.137 & 1.080 \\
\hline & 60.0 & 1.217 & 1.087 & 1.187 & & 60.0 & 1.250 & 1.630 & 1.077 \\
\hline
\end{tabular}

Table (6- $\mathrm{c}$ ) the interaction between BxC

\begin{tabular}{|c|c|c|c|c|c|c|c|c|c|}
\hline \multirow{3}{*}{\begin{tabular}{|l|} 
Organic \\
manure source \\
"'B"
\end{tabular}} & \multicolumn{9}{|c|}{ Applied inoculate "C" } \\
\hline & \multicolumn{4}{|c|}{ First season } & \multicolumn{5}{|c|}{ Second season } \\
\hline & 0.0 & \multicolumn{2}{|c|}{ T16 } & T26 & 0.0 & \multicolumn{2}{|c|}{ T16 } & \multicolumn{2}{|c|}{ T26 } \\
\hline \multirow{3}{*}{$\begin{array}{l}0.0 \\
\text { Chicken } \\
\text { Sheep } \\
\end{array}$} & 1.452 & \multicolumn{2}{|c|}{1.33} & 1.272 & 1.500 & \multicolumn{2}{|c|}{1.363} & \multicolumn{2}{|c|}{1.248} \\
\hline & 1.248 & \multicolumn{2}{|c|}{1.165} & 1.090 & 1.302 & \multicolumn{2}{|c|}{1.198} & \multicolumn{2}{|c|}{1.112} \\
\hline & 1.358 & \multicolumn{2}{|c|}{1.288} & 1.208 & 1.410 & \multicolumn{2}{|c|}{1.290} & & \\
\hline \multirow{3}{*}{$\underset{\%}{\text { L. S. D. at }} \frac{5}{\frac{F}{S}}$} & & & $\mathbf{A}$ & $\mathbf{B}$ & $\mathbf{C}$ & AxB & $A \times C$ & BxC & $\mathrm{AxB} \times \mathrm{C}$ \\
\hline & st seas & & 0.148 & 0.083 & 0.141 & 0.166 & 0.209 & 0.181 & 0.362 \\
\hline & cond se & son & 0.077 & 0.013 & 0.070 & 0.096 & 0.139 & 0.111 & 0.292 \\
\hline
\end{tabular}


Application of $45 \mathrm{~kg} \mathrm{~N} /$ fed $\times$ T26 showed the highest value These results are quite similar with those obtained on squash by Abd-El-Fattah and Sorial (2000). With regard to the interaction between $B \times C$, significant increase was noticed. Early yield ( $\mathrm{kg} / \mathrm{plant}$ ) obtained from the interaction of chicken manure x T26 showed the highest values for both seasons. The values obtained from each interaction surpassed those obtained from single treatment. The interaction of $45 \mathrm{~kg} \mathrm{~N} \times$ chicken manure showed the highest value followed by the application of $45 \mathrm{~kg} \mathrm{~N} \times$ T26, whereas applications of chicken manure $x$ T26 showed the lowest value.

In general, the interactions of the three factors had significant effect, in both seasons. Among these interactions, the highest values of early yield per plant were obtained from chemical $\mathrm{N}$ at $45 \mathrm{~kg}$ / fed., $\mathrm{x}$ chicken manure $\mathrm{x}$ T26. Again, the triple interactions were more effective in this character than application of one or two sorts of fertilizers.

$2-2$ - Number of total fruits / plant: -

Data in Tables $(8,8 \mathrm{a}, \mathrm{b} \& \mathrm{c})$ indicated that application of chemical $\mathrm{N}$ rate, organic manure or biofertilizer significantly increased the number of total fruits / plant. Application of chemical $\mathrm{N}$ rate markedly increased the number of total fruits / plant, in both seasons. The highest values were obtained from 60 $\mathrm{kg} \mathrm{N}$ / fed., with insignificant difference with that obtained from $45 \mathrm{~kg} \mathrm{~N} /$ fed. Chicken manure gave the higher value than sheep manure in this character. Also, T26 surpassed T16 in this parameter. Increasing number of total fruits / plant with increasing chemical nitrogen rates agreed with that obtained on squash as reported by Pelaez (1984); Wagih et al., (1986); Abd-el-Fattah and Sorial (2000), and on pumpkin by Feleafel (2000). In addition various organic materials had increased number of total fruits / plant which agreed with that obtained on pea by El-Mansi et al., (1999); on potato by Abo-Hussein (1995), and Abd-El-Fattah and Sorial (2000). Increasing number of total fruit / plant with inoculation biofertilizers agreed with that obtained on tomato by Dakhly and Abd-El-Mageed (1997). With regard to the interactions of $A \times B$, significant effect on number of total fruits per plant were obtained, in both seasons. The highest number were observed from plants treated with $45 \mathrm{~kg}$ $\mathrm{N} /$ fed., $\mathrm{x}$ chicken manure.

Concerning the interactions of $\mathrm{A} \times \mathrm{C}$, results showed significant increase in number of total fruits / plant, in both seasons. Application of $45 \mathrm{~kg}$ $\mathrm{N} /$ fed., x T26 resulted in the highest values. Concerning the interactions between $\mathrm{B} \times \mathrm{C}$, significant increase in this parameter was gained, in both seasons. The highest value in number of total fruits / plant was resulted from the interaction between chicken manure $x$ T26. Regarding, the triple interactions of chemical $\mathrm{N}$ rates, organic manure and biofertilizers data obtained showed significant effect in both seasons. Among these interactions, the highest values of number of total fruits / plant were obtained from application of $\mathrm{N}$ at $45 \mathrm{~kg} \mathrm{~N} /$ fed., $\mathrm{x}$ chicken manure $\times \mathrm{T} 26$. 
Hassan, E. A. et al.

Table (7): Effects of $\mathbf{N}$ - chemical rates / fed., organic manure source or / and biofertilizer inoculums on Early squash yield $\mathrm{kg} /$ plant during the two autumn seasons.

\begin{tabular}{|c|c|c|c|c|c|c|c|c|c|c|c|c|c|}
\hline \multirow{5}{*}{$\begin{array}{l}\text { Organic } \\
\text { source } \\
\text { "B" }\end{array}$} & \multicolumn{13}{|c|}{ First season } \\
\hline & \multicolumn{12}{|c|}{ Chemical N- rates / fed. "A" } & \multirow{4}{*}{$\begin{array}{l}\text { Mean } \\
\text { "B" }\end{array}$} \\
\hline & \multicolumn{3}{|c|}{$0.0 \mathrm{~kg}$} & \multicolumn{3}{|c|}{$30.0 \mathrm{~kg}$} & \multicolumn{3}{|c|}{$45.0 \mathrm{~kg}$} & \multirow{2}{*}{\multicolumn{3}{|c|}{$60.0 \mathrm{~kg}$}} & \\
\hline & \multicolumn{9}{|c|}{ Applied inoculate "C" } & & & & \\
\hline & 0.0 & $T_{16}$ & $T_{26}$ & 0.0 & $T_{16}$ & $T_{26}$ & 0.0 & $T_{16}$ & $T_{26}$ & 0.0 & $T_{16}$ & $T_{26}$ & \\
\hline 0.0 & 0.016 & 0.053 & 0.040 & 0.123 & 0.097 & 0.105 & 0.162 & 0.190 & 0.211 & 0.185 & 0.153 & 0.150 & 0.124 \\
\hline Chicken & 0.060 & 0.140 & 0.160 & 0.140 & 0.155 & 0.178 & 0.273 & 0.257 & 0.288 & 0.215 & 0.2345 & 0.247 & 0.195 \\
\hline Sheep & 0.048 & 0.102 & 0.110 & 0.110 & 0.133 & 0.161 & 0.225 & 0.238 & 0.246 & 0.199 & 0.249 & 0.230 & 0.171 \\
\hline Mean"A" & & 0.080 & & & 0.133 & & \multicolumn{3}{|c|}{0.232} & \multicolumn{4}{|c|}{0.207} \\
\hline Mean"C" & \multicolumn{6}{|c|}{0.0 untreated $=0.146$} & & $16=0.16$ & & & $T_{26}=$ & $=0.177$ & \\
\hline \multicolumn{14}{|c|}{ Second season } \\
\hline 0.0 & 0.013 & 0.040 & 0.035 & 0.197 & 0.088 & 0.108 & 0.159 & 0.190 & 0.210 & 0.161 & 0.127 & 0.147 & 0.123 \\
\hline Chic & 0.065 & 0.135 & 0.148 & 0.138 & 0.1 & 0.168 & 0.243 & 0.244 & 0.261 & 0.183 & 0.208 & 0.226 & 0.181 \\
\hline Sheep & 0.055 & 0.098 & 0.085 & 0.104 & 0.126 & 0.150 & 0.212 & 0.227 & 0.235 & 0.176 & 0.195 & 0.216 & 0.156 \\
\hline Mean "A & \multirow{2}{*}{\multicolumn{3}{|c|}{$\frac{0.075}{0.0 \text { untre }}$}} & \multirow{2}{*}{\multicolumn{3}{|c|}{$\begin{array}{c}0.136 \\
=0.142\end{array}$}} & \multicolumn{3}{|c|}{0.221} & \multicolumn{4}{|c|}{0.182} \\
\hline Mean "C & & & & & & & \multicolumn{3}{|c|}{$T_{16}=0.152$} & \multicolumn{4}{|c|}{16} \\
\hline
\end{tabular}

Table (7-a) the interaction between AxB Table (7-b) the interaction between AxC

\begin{tabular}{|c|c|c|c|c|c|c|c|c|c|}
\hline & \multirow{2}{*}{\begin{tabular}{|c|} 
Chemical \\
N-rate/ \\
fed., "A"
\end{tabular}} & \multicolumn{3}{|c|}{\begin{tabular}{|c} 
Organic manure source \\
"B "
\end{tabular}} & & \multirow{2}{*}{$\begin{array}{c}\text { Chemical } \\
\text { N-rate/ } \\
\text { fed., "A" }\end{array}$} & \multicolumn{3}{|c|}{ Applied inoculate "C" } \\
\hline & & 0.0 & Chicken & Sheep & & & 0.0 & T16 & T26 \\
\hline \multirow{4}{*}{$\begin{array}{l}\text { First } \\
\text { season }\end{array}$} & \begin{tabular}{|l|} 
\\
\end{tabular} & 0.036 & & & \multirow{4}{*}{$\begin{array}{l}\text { First } \\
\text { season }\end{array}$} & 0.0 & 0.041 & 0.097 & 0.103 \\
\hline & 30.0 & & & & & 0 & & & 0.148 \\
\hline & 45.0 & 0.188 & 0.272 & 0.2 & & 45.0 & 0.220 & 0.228 & 0.248 \\
\hline & 60.0 & 0.1 & 0.232 & & & 60.0 & 0.120 & 0.212 & 0.209 \\
\hline \multirow{4}{*}{$\begin{array}{l}\text { Second } \\
\text { season }\end{array}$} & 0 & 0.029 & & & \multirow{4}{*}{$\begin{array}{l}\text { Second } \\
\text { season }\end{array}$} & 00 & 14 & 0.091 & 0.089 \\
\hline & 30 & & & & & & & & 0.142 \\
\hline & 45.0 & 0.186 & 0.251 & 0.224 & & 45.0 & 0.205 & 0.222 & 0.235 \\
\hline & 60.0 & 0.145 & 0.206 & 0.196 & & 60.0 & 0.173 & 0.177 & 0.196 \\
\hline
\end{tabular}

Table (7- c) the interaction between BxC

\begin{tabular}{|c|c|c|c|c|c|c|c|c|c|}
\hline \multirow{3}{*}{$\begin{array}{l}\text { Organic } \\
\text { manure source } \\
\text { “B” }\end{array}$} & \multicolumn{9}{|c|}{ Applied inoculate "C" } \\
\hline & \multicolumn{4}{|c|}{ First season } & \multicolumn{5}{|c|}{ Second season } \\
\hline & 0.0 & \multicolumn{2}{|c|}{ T16 } & T26 & 0.0 & \multicolumn{2}{|c|}{ T16 } & \multicolumn{2}{|c|}{ T26 } \\
\hline & 0.122 & \multicolumn{2}{|c|}{0.123} & 0.127 & 0.133 & \multicolumn{2}{|c|}{0.111} & \multicolumn{2}{|c|}{0.125} \\
\hline Chicken & 0.172 & \multicolumn{2}{|c|}{0.196} & 0.218 & 0.157 & \multicolumn{2}{|c|}{0.184} & \multicolumn{2}{|c|}{0.201} \\
\hline Sheep & 0.145 & 0.18 & & 0.187 & 0.137 & & & & \\
\hline \multirow{3}{*}{ L. S. D. at 5} & & & $\mathbf{A}$ & B & $\mathbf{C}$ & AxB & AxC & BxC & AxBxC \\
\hline & st seasc & & 0.034 & $\begin{array}{ll}4 & 0.026\end{array}$ & 0.027 & 0.051 & 0.053 & 0.045 & 0.09 \\
\hline & cond se & son & 0.029 & \begin{tabular}{l|l|}
9 & 0.018 \\
\end{tabular} & 0.020 & 0.047 & 0.050 & 0.04 & 0.081 \\
\hline
\end{tabular}

\section{2-3- Average fruit weight $(\mathrm{g})$ : -}

Data in Tables $(9,9 a, b \& c)$ indicated that average fruit weight were significantly increased with application of chemical $\mathrm{N}$ rates, organic manures or biofertilizers in both seasons. Among the various chemical $\mathrm{N}$ rates, application of $45 \mathrm{~kg} \mathrm{~N} /$ fed., showed the highest values which were similar to those obtained from $60 \mathrm{~kg} \mathrm{~N} /$ fed., (56 and $59 \mathrm{~g}$ ) whereas chicken manure surpassed sheep manure in this character ( 54 and 55 versus 52 and $53 \mathrm{~g}$ ) and T16 resulted in higher values than T26 (52 and 51 versus 54 and $53 \mathrm{~g}$ ) for the first and second seasons, respectively. However, these results indicate that quite similar responses in this character due to these treatments 
were obtained. Application of various organic fertilizers increased average fruit weight (g), this result agreed with that obtained on potato by AboHussein (1995); and on cucumber by Alphonse and Saad (2000a). Increasing average fruit weight with inoculation biofertilizers agreed with that obtained on tomato as reported by Ali and Selim (1996); and on potato by Ashour et al. (1997); Ibrahim and Aly (1999), Fatma and Ali (2001) and Gardner and Pew (1997).

Regarding the interactions between $\mathrm{A} \times \mathrm{B}$, significant increase in average fruit weight were obtained, in both seasons. The highest values were observed from the application of 45 or $60 \mathrm{~kg} / \mathrm{fed}$., $x$ chicken manure with insignificant difference between their means, in both seasons. Concerning the interactions between $\mathrm{A} \times \mathrm{C}$, significant increase in this character were gained, in both seasons. Application of $45 \mathrm{~kg} \mathrm{~N} / \mathrm{fed}$., x T26 or T16 showed the highest value with insignificant difference between their means, in both seasons. These results are quite similar with those obtained by Abd-El-Fattah and Sorial (2000). The interactions between B x C, showed significant effect on average fruit weight. Application of organic manure $\mathrm{x}$ biofertilizers showed significant increase, where chicken manure $\times$ T16 resulted in the highest values. However, the interaction of chicken manure x T26 showed quite similar response in this character as compared with $45 \mathrm{~kg} \mathrm{~N} / \mathrm{fed}$. With respect to the interactions between the three factors significant effect was obtained. Among these interactions, the highest values of average fruit weight were obtained for chemical $\mathrm{N}$ at $45 \mathrm{~kg} \mathrm{~N} /$ fed., $\mathrm{x}$ chicken manure $\mathrm{x}$ T26 i.e.; 65 and $66(\mathrm{~g})$ for the first and second seasons, respectively. Again, the triple interactions were more effective in this character than that obtained from one or two sorts of fertilizers.

Table (8): Effects of $\mathbf{N}$ - chemical rates / fed., organic manure source or / and biofertilizer inoculums on Number of total squash fruits / plant during the two autumn seasons.

\begin{tabular}{|c|c|c|c|c|c|c|c|c|c|c|c|c|c|}
\hline \multirow{5}{*}{$\begin{array}{l}\text { Organic } \\
\text { source } \\
\text { "B" }\end{array}$} & \multicolumn{13}{|c|}{ First season } \\
\hline & \multicolumn{12}{|c|}{ Chemical N- rates / fed. "A" } & \multirow{4}{*}{ Mean } \\
\hline & \multicolumn{3}{|c|}{$0.0 \mathrm{~kg}$} & \multicolumn{3}{|c|}{$30.0 \mathrm{~kg}$} & \multicolumn{3}{|c|}{$45.0 \mathrm{~kg}$} & \multirow{2}{*}{\multicolumn{3}{|c|}{$60.0 \mathrm{~kg}$}} & \\
\hline & \multicolumn{9}{|c|}{ Applied inoculate "C" } & & & & \\
\hline & 0.0 & $T_{16}$ & $\mathbf{T}_{26}$ & 0.0 & $T_{16}$ & $T_{26}$ & 0.0 & $T_{16}$ & $\mathbf{T}_{26}$ & 0.0 & $T_{16}$ & $\mathbf{T}_{26}$ & \\
\hline 0.0 & 4.8 & 5.5 & 5.8 & 10.7 & 13.1 & 14.5 & 14.1 & 14.6 & 15.9 & 14.8 & 15.3 & 15.6 & 12.045 \\
\hline Chicken & 8.2 & 9.5 & 12.4 & 16.9 & 16.9 & 17.6 & 18.2 & 19.4 & 20.9 & 19.2 & 20.3 & 18.5 & 16.497 \\
\hline Sheep & 6.4 & 7.8 & 10.9 & 14.7 & 14.9 & 16.4 & 16.5 & 17.9 & 18.4 & 17.3 & 19.3 & 17.8 & 14.825 \\
\hline Mean"A" & \multicolumn{3}{|c|}{7.915} & \multicolumn{3}{|c|}{15.074} & \multicolumn{3}{|c|}{17.324} & \multicolumn{4}{|c|}{17.545} \\
\hline Mean"C" & \multicolumn{6}{|c|}{0.0 untreated $=13.461$} & \multicolumn{3}{|c|}{$T_{16}=14.5$} & \multicolumn{4}{|c|}{$T_{26}=15.409$} \\
\hline \multicolumn{14}{|c|}{ Second season } \\
\hline 0.0 & 4.7 & 5.3 & 5.5 & 9.9 & 13.3 & 14.2 & 13.5 & 14.4 & 15.7 & 14.4 & 14.9 & 15.3 & 11.763 \\
\hline Chicken & 8.5 & 8.5 & 11.5 & 15.8 & 16.4 & 17.3 & 17.7 & 19.3 & 20.5 & 18.4 & 19.5 & 18.8 & 16.015 \\
\hline Sheep & 6.8 & 7.5 & 10.4 & 14.6 & 14.8 & 15.7 & 15.7 & 17.8 & 18.6 & 16.8 & 18.9 & 17.6 & 14.593 \\
\hline Mean "A & \multicolumn{3}{|c|}{7.631} & \multicolumn{3}{|c|}{14.668} & \multicolumn{3}{|c|}{17.011} & \multicolumn{4}{|c|}{17.18} \\
\hline Mean "C & \multicolumn{6}{|c|}{0.0 untreated $=13.06$} & \multicolumn{3}{|c|}{$\mathrm{T}_{16}=14.215$} & \multicolumn{4}{|c|}{$\mathrm{T}_{26}=15.095$} \\
\hline
\end{tabular}


Hassan, E. A. et al.

Table (8-a) the interaction between AxB Table (8-b) the interaction between AxC

\begin{tabular}{|c|c|c|c|c|c|c|c|c|c|}
\hline & \multirow{2}{*}{$\begin{array}{c}\text { Chemical } \\
\text { N-rate/ } \\
\text { fed., "A" }\end{array}$} & \multicolumn{3}{|c|}{$\begin{array}{c}\text { Organic manure source " } \\
\text { B " }\end{array}$} & & \multirow{2}{*}{$\begin{array}{c}\text { Chemical } \\
\text { N-rate/ } \\
\text { fed., "A'" }\end{array}$} & \multicolumn{3}{|c|}{ Applied inoculate "C" } \\
\hline & & 0.0 & Chicken & Sheep & & & 0.0 & T16 & T26 \\
\hline $\begin{array}{l}\text { First } \\
\text { season }\end{array}$ & \begin{tabular}{|c|}
0.0 \\
30.0 \\
45.0 \\
60.0
\end{tabular} & $\begin{array}{c}5.4 \\
12.8 \\
14.9 \\
15.2\end{array}$ & $\begin{array}{l}10.0 \\
17.1 \\
19.5 \\
19.3\end{array}$ & $\begin{array}{c}8.4 \\
15.3 \\
17.6 \\
18.1\end{array}$ & $\begin{array}{l}\text { First } \\
\text { season }\end{array}$ & $\begin{array}{c}0.0 \\
30.0 \\
45.0 \\
60.0\end{array}$ & $\begin{array}{c}6.5 \\
14.1 \\
16.3 \\
17.1\end{array}$ & $\begin{array}{c}7.6 \\
14.9 \\
17.3 \\
18.3\end{array}$ & $\begin{array}{c}9.7 \\
16.2 \\
18.4 \\
17.3\end{array}$ \\
\hline $\begin{array}{l}\text { Second } \\
\text { season }\end{array}$ & $\begin{array}{c}0.0 \\
30.0 \\
45.0 \\
60.0\end{array}$ & $\begin{array}{c}5.2 \\
12.5 \\
14.5 \\
14.9\end{array}$ & $\begin{array}{c}9.5 \\
16.5 \\
19.2 \\
18.9\end{array}$ & $\begin{array}{c}8.2 \\
15.0 \\
17.4 \\
17.8\end{array}$ & $\begin{array}{l}\text { Second } \\
\text { season }\end{array}$ & $\begin{array}{c}0.0 \\
30.0 \\
45.0 \\
60.0\end{array}$ & $\begin{array}{c}6.6 \\
13.4 \\
15.6 \\
16.5\end{array}$ & $\begin{array}{c}7.1 \\
14.8 \\
17.1 \\
17.8\end{array}$ & $\begin{array}{c}9.1 \\
15.7 \\
18.3 \\
17.2\end{array}$ \\
\hline
\end{tabular}

Table (8 - c) the interaction between BxC

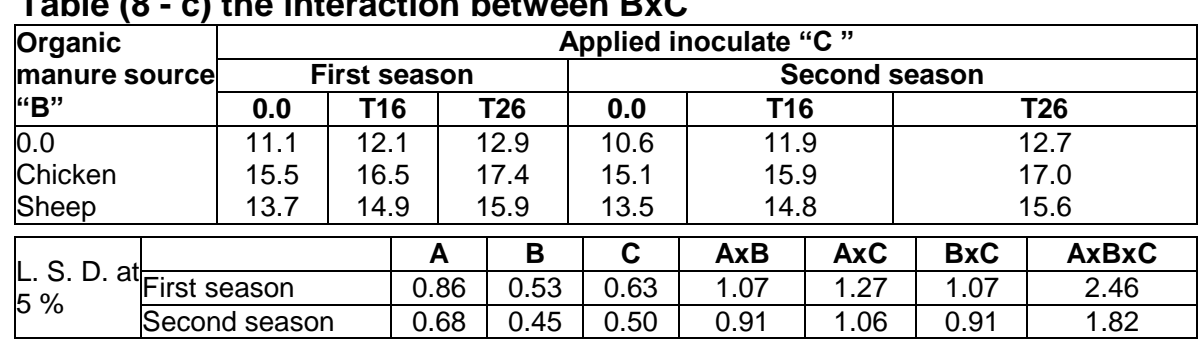

Table (9): Effects of $\mathbf{N}$ - chemical rates / fed., organic manure source or / and biofertilizer inoculums on Average squash fruit weight (g) / plant during the two autumn seasons.

\begin{tabular}{|c|c|c|c|c|c|c|c|c|c|c|c|c|c|}
\hline \multirow{5}{*}{$\begin{array}{l}\text { Organic } \\
\text { source } \\
\text { "B" }\end{array}$} & \multicolumn{13}{|c|}{ First season } \\
\hline & \multicolumn{12}{|c|}{ Chemical N- rates / fed. "A" } & \multirow{4}{*}{$\begin{array}{c}\text { Mean } \\
\text { "B" }\end{array}$} \\
\hline & & $0.0 \mathrm{~kg}$ & & & $30.0 \mathrm{~kg}$ & & & $45.0 \mathrm{~kg}$ & & & $60.0 \mathrm{~kg}$ & & \\
\hline & \multicolumn{12}{|c|}{ Applied inoculate "C" } & \\
\hline & 0.0 & $T_{16}$ & $T_{26}$ & 0.0 & $T_{16}$ & $T_{26}$ & 0.0 & $T_{16}$ & $T_{26}$ & 0.0 & $T_{16}$ & $T_{26}$ & \\
\hline 0.0 & 0.011 & 0.023 & 0.024 & 0.043 & 0.041 & 0.042 & 0.042 & 0.051 & 0.060 & 0.055 & 0.052 & 0.045 & 0.041 \\
\hline Chicken & 0.024 & 0.059 & 0.053 & 0.045 & 0.051 & 0.052 & 0.056 & 0.057 & 0.065 & 0.063 & 0.061 & 0.056 & 0.054 \\
\hline Sheep & 0.030 & 0.048 & 0.049 & 0.043 & 0.049 & 0.051 & 0.059 & 0.054 & 0.062 & 0.058 & 0.059 & 0.057 & 0.052 \\
\hline Mean"A" & & 0.036 & & & 0.046 & & \multicolumn{3}{|c|}{0.056} & \multicolumn{4}{|c|}{0.056} \\
\hline Mean“C" & \multicolumn{6}{|c|}{0.0 untreated $=0.044$} & & $6=0.0$ & & & $T_{26}=$ & 0.051 & \\
\hline \multicolumn{14}{|c|}{ Second season } \\
\hline 0.0 & 0.012 & 0.024 & 0.024 & 0.045 & 0.044 & 0.044 & 0.045 & 0.051 & 0.061 & 0.058 & 0.052 & 0.048 & 0.044 \\
\hline Chic & 0.029 & 0.058 & 0.051 & 0.047 & 0.051 & 0.053 & 0.063 & 0.063 & 0.066 & 0.061 & 0.062 & 0.064 & 0.055 \\
\hline Sheep & 0.032 & 0.052 & 0.051 & 0.043 & 0.051 & 0.053 & 0.058 & 0.057 & 0.066 & 0.061 & 0.062 & 0.062 & 0.053 \\
\hline Mean "A & \multirow{2}{*}{\multicolumn{3}{|c|}{$\frac{0.037}{0.0 \text { un }}$}} & \multirow{2}{*}{\multicolumn{3}{|c|}{0.048}} & \multirow{2}{*}{\multicolumn{3}{|c|}{$\begin{array}{c}0.059 \\
16=0.05\end{array}$}} & \multicolumn{4}{|c|}{0.059} \\
\hline Mean "C & & & & & & & & & & & & .05 & \\
\hline
\end{tabular}

\section{Table (9-a) the interaction between AxB Table (9-b) the interaction between AxC}

\begin{tabular}{|c|c|c|c|c|c|c|c|c|c|}
\hline & \multirow{2}{*}{$\begin{array}{c}\text { Chemical } \\
\text { N-rate/ } \\
\text { fed., "A" }\end{array}$} & \multicolumn{3}{|c|}{$\begin{array}{c}\text { Organic manure source } \\
\text { "B " }\end{array}$} & & \multirow{2}{*}{$\begin{array}{c}\text { Chemical } \\
\text { N-rate/ } \\
\text { fed., "A" }\end{array}$} & \multicolumn{3}{|c|}{ Applied inoculate " $C$ " } \\
\hline & & \begin{tabular}{|l|}
0.0 \\
\end{tabular} & \begin{tabular}{|l|} 
Chicken \\
\end{tabular} & Sheep & & & 0.0 & T16 & T26 \\
\hline \multirow{4}{*}{$\begin{array}{l}\text { First } \\
\text { season }\end{array}$} & 0.0 & 0.019 & 0.045 & 0.042 & \multirow{4}{*}{$\begin{array}{l}\text { First } \\
\text { season }\end{array}$} & 0.0 & 0.022 & 0.043 & 0.042 \\
\hline & 30.0 & 0.0 & 0.0 & & & & & & 0.048 \\
\hline & 45.0 & 0.051 & 0.059 & 0.0 & & 45 & 0.052 & 0.0 & 0.062 \\
\hline & 60.0 & 0.051 & 0.060 & 0. & & 60.0 & 0.059 & 0.057 & 0.053 \\
\hline \multirow{4}{*}{$\begin{array}{l}\text { Second } \\
\text { season }\end{array}$} & 0.0 & 0.020 & 0.046 & 0. & \multirow{4}{*}{$\begin{array}{l}\text { Second } \\
\text { season }\end{array}$} & 0.0 & $0 . C$ & 0.045 & 0.042 \\
\hline & 30 & & 0.05 & & & & & & 0.050 \\
\hline & 45.0 & 0.052 & 0.064 & 0.060 & & 45. & 0.055 & 0.057 & 0.064 \\
\hline & 60.0 & 0.053 & 0.062 & 0.061 & & 60.0 & 0.060 & 0.059 & 0.057 \\
\hline
\end{tabular}


Table $(9-c)$ the interaction between BxC

\begin{tabular}{|c|c|c|c|c|c|c|c|c|}
\hline \multirow{3}{*}{$\begin{array}{l}\text { Organic } \\
\text { manure source } \\
\text { "B” }\end{array}$} & \multicolumn{8}{|c|}{ Applied inoculate "C" } \\
\hline & \multicolumn{3}{|c|}{ First season } & \multicolumn{5}{|c|}{ Second season } \\
\hline & 0.0 & T16 & T26 & 0.0 & \multicolumn{2}{|c|}{ T16 } & \multicolumn{2}{|c|}{ T26 } \\
\hline 0.0 & 0.038 & 0.042 & 0.043 & 0.040 & \multicolumn{2}{|c|}{0.043} & \multicolumn{2}{|c|}{0.048} \\
\hline Chicken & 0.047 & 0.057 & 0.057 & 0.050 & \multirow{2}{*}{\multicolumn{2}{|c|}{$\begin{array}{l}0.059 \\
0.059\end{array}$}} & \multirow{2}{*}{\multicolumn{2}{|c|}{$\begin{array}{l}0.055 \\
0.057\end{array}$}} \\
\hline Sheep & 0.047 & 0.053 & 0.055 & 0.044 & & & & \\
\hline \multirow{3}{*}{$\mid \begin{array}{l}\text { L. S. D. at } \\
5 \%\end{array}$} & & A & B & C & AxB & AxC & BxC & AxBxC \\
\hline & eason & 0.005 & 0.006 & 0.007 & 0.012 & 0.014 & 0.012 & 0.024 \\
\hline & d season & 0.005 & 0.006 & 0081 & 0.012 & 0.016 & 0.014 & 0.028 \\
\hline
\end{tabular}

2-4- Total yield (ton / fed.): -

Data in Tables $(10,10 a, b \& c)$ indicated that application of chemical-N rates, organic manure or biofertilizers had significantly increased the total yield (ton / fed.), in both seasons. Among the various chemical $\mathrm{N}$-rates, the heaviest total yield was obtained from plants that received $60.0 \mathrm{~kg} \mathrm{~N} /$ fed., with insignificant difference with that obtained from plants which had received $45.0 \mathrm{~kg} \mathrm{~N} /$ fed., i.e.; 13.71 and 12.85 versus 13.63 and 12.76 ton/fed., for the first and second seasons, respectively. Among the organic manures, chicken manure showed higher total yield than that obtained from sheep manure i.e.; 12.52 and 11.66 vs. 10.94 and 10.29 ton, for the first and second seasons, respectively. For the biofertilizers, T26 resulted in higher values than T16 (11.400 and 10.73 versus 10.48 and 9.84 ton / fed.) for the first and second seasons, respectively. It is clear from the obtained data that $\mathrm{N}$-chemical fertilizer at $45.0 \mathrm{~kg} \mathrm{~N} / \mathrm{fed}$., was the most superior on this parameter and chicken manure was intermediate and T26 showed the lowest total yield. However, either chicken manure or T26 were effective on this character in the range between 30.0 and $45.0 \mathrm{~kg} \mathrm{~N} /$ fed. Increasing total yield (ton / fed.) with increasing chemical $\mathrm{N}$ fertilizer rates agreed with those obtained on pumpkin by Das and Swain (1977); Rajendran (1983), Swiader et al., (1988); Reiners and Riggs (1997) and Feleafel et al. (2000) , on squash by Huett (1986); Huett and Dettmann, (1988), Hilal and Selim (1992); Abd-El-Fattah and Sorial (2000); and on melons by Buwalda and Freeman (1986). Application of organic manures had increased total yield. These results agreed with those obtained on some vegetables as reported by Maynard (1989); on onion by Warade et al., (1995), on vegetables by Warman and Harvard (1996); on tomato by Alexiev and Rankov (1997); on pepper by El-Qassas et al.(1997); on pea by El-Mansi et al., (1999); and on cucumper by Alphonse and Saad (2000a). Increasing total yield with inoculation biofertilizers agreed with that obtained on squash Hassan et al. (2000), on tomato as reported by Rovira (1963), Shahaby et al. (1993), Ali and Selim (1996); and on potato by Fayez (1981); Pandey and Kumar (1989), Sidorenko et al. (1996), Ashour et al., (1997), Ibrahim and Aly (1999); and Fatma and Ali (2001); and on carrot and tomato by Dakhly and Abd-El-Mageed (1997); and on okra by Ganeshe, et al., (1998); and on squash by Abd-El-Fattah and Sorial (2000).

Regarding the interaction between $\mathrm{N}$ rates and organic manure significant effect was obtained, in both seasons. The highest values were obtained from plants treated with $45.0 \mathrm{~kg} \mathrm{~N} / \mathrm{fed}$., $\mathrm{x}$ chicken manure (16.50 
and 15.06 ton / fed.) for the first and second seasons, respectively. Also, the interactions between $\mathrm{A} \times \mathrm{C}$ resulted in significant increase in total yield (ton / fed.). The heaviest total yield (ton / fed.) were obtained from plants received $45 \mathrm{~kg} / \mathrm{fed}$., $x$ T26. These results are in line with those obtained on sweet potato by Jadhav et al., (1998); on carrot Wange (1996); and on squash by Abd-El-Fattah and Sorial (2000). Concerning, the interactions between B x C, significant increase were obtained in both seasons. Total yield (ton / fed.) from the interaction of chicken manure x T26 showed the highest values (13.68 and 12.86 ton / fed.), which were in the range of that obtained from application of $45 \mathrm{~kg} \mathrm{~N} /$ fed.

The interactions between the three factors showed significant effect in both seasons. Among these interactions, the highest values of total yield (ton / fed.) were obtained from application of chemical- $\mathrm{N}$ at $45.0 \mathrm{~kg} / \mathrm{fed}$., $\mathrm{x}$ chicken manure x T26 i.e.; 18.35 and 17.69 ton / fed., for the first and second seasons, respectively. Again, the triple interactions were more effective in this character than that obtained from one or two sort of fertilizers.

Table (10): Effects of $\mathrm{N}$ - chemical rates / fed., organic manure source or / and biofertilizer inoculums on total squash yield (ton / fed.) during the two autumn seasons.

\begin{tabular}{|c|c|c|c|c|c|c|c|c|c|c|c|c|c|}
\hline \multirow{5}{*}{$\begin{array}{l}\text { Organic } \\
\text { source } \\
\text { "B" }\end{array}$} & \multicolumn{13}{|c|}{ First season } \\
\hline & \multicolumn{12}{|c|}{ Chemical N- rates / fed. "A" } & \multirow{4}{*}{$\begin{array}{l}\text { Mean } \\
\text { "B" }\end{array}$} \\
\hline & \multicolumn{3}{|c|}{$0.0 \mathrm{~kg}$} & \multirow{2}{*}{\multicolumn{3}{|c|}{$30.0 \mathrm{~kg}$}} & \multicolumn{3}{|c|}{$45.0 \mathrm{~kg}$} & \multirow{2}{*}{\multicolumn{3}{|c|}{$60.0 \mathrm{~kg}$}} & \\
\hline & \multicolumn{6}{|c|}{ noculate "C" } & & & & & & & \\
\hline & 0.0 & $T_{16}$ & $T_{26}$ & 0.0 & $T_{16}$ & $T_{26}$ & 0.0 & $T_{16}$ & $T_{26}$ & 0.0 & $T_{16}$ & $T_{26}$ & \\
\hline 0.0 & 0.766 & 1.716 & 1.881 & 6.399 & 7.587 & 8.445 & 8.28 & 9.864 & 12.93 & 11.38 & 810.52 & 9.90 & 7.473 \\
\hline Chicken & 3.135 & 7.227 & 8.415 & 10.48 & 11.49 & 12.34 & 14.98 & 16.17 & 18.35 & 15.48 & \begin{tabular}{|l|l|}
8 & 16.60 \\
\end{tabular} & 15.62 & 12.52 \\
\hline Sheep & 2.706 & 5.346 & 7.293 & 8.478 & 9.996 & 11.42 & 1257 & 13.49 & 16.07 & 13.99 & 915.76 & 14.15 & 10.94 \\
\hline Mean"A" & & 4.276 & & & 9.625 & & & 13.633 & & \multirow{2}{*}{\multicolumn{4}{|c|}{$\frac{13.710}{T_{26}=11.400}$}} \\
\hline Mean"C" & \multicolumn{6}{|c|}{0.0 untreated $=9.054$} & \multicolumn{3}{|c|}{$T_{16}=10.480$} & & & & \\
\hline \multicolumn{14}{|c|}{ Second season } \\
\hline 0.0 & 0.652 & 1.584 & 1.782 & 5.61 & 7.128 & 7.92 & 7.498 & 9.67 & 12.43 & 10.55 & \begin{tabular}{|l|l|}
510.23 \\
\end{tabular} & 9.134 & 7.015 \\
\hline Chicken & 2.706 & 6.745 & 8.012 & 9.73 & 11.01 & 11.88 & 13.04 & 14.45 & 17.69 & 15.18 & \begin{tabular}{|l|l|}
8 & 15.64 \\
\end{tabular} & 13.86 & 11.66 \\
\hline Sheep & 2.548 & 4.782 & 6.798 & 8.25 & 9.491 & 10.51 & 12.13 & 12.58 & 15.33 & 12.87 & $\begin{array}{l}714.72 \\
7\end{array}$ & 13.44 & 10.29 \\
\hline Mean "A & & 3.958 & & & 9.058 & & \multirow{2}{*}{\multicolumn{3}{|c|}{$\frac{12.10}{16}=9.837$}} & \multicolumn{4}{|c|}{12.85} \\
\hline Mean "C & \multicolumn{6}{|c|}{0.0 untreated $=8.397$} & & & & & $T_{26}=$ & $=10.73$ & \\
\hline
\end{tabular}

Table (10 - a) the interaction between AxB Table (10-b) the interaction between AxC

\begin{tabular}{|c|c|c|c|c|c|c|c|c|c|}
\hline & \multirow{2}{*}{$\begin{array}{c}\text { Chemical } \\
\text { N-rate/ } \\
\text { fed., "A" }\end{array}$} & \multicolumn{3}{|c|}{$\begin{array}{c}\text { Organic manure source } \\
\text { " B " }\end{array}$} & & \multirow{2}{*}{$\begin{array}{c}\text { Chemical } \\
\text { N-rate/ } \\
\text { fed., "A" }\end{array}$} & \multicolumn{3}{|c|}{ Applied inoculate " $C$ " } \\
\hline & & 0.0 & Chicken & Sheep & & & 0.0 & T16 & T26 \\
\hline & 0.0 & 1.454 & 6.259 & 5.115 & & 0.0 & 2.202 & 4.763 & 5.863 \\
\hline & 30.0 & 7.477 & 11.44 & 9.963 & First & 30.0 & 8.453 & 9.691 & 10.73 \\
\hline \multirow{2}{*}{ season } & 45.0 & 10.36 & 16.50 & 14.04 & season & 45.0 & 11.94 & 13.17 & 15.78 \\
\hline & 60.0 & 10.60 & 15.90 & 14.63 & & 60.0 & 13.62 & 14.29 & 13.22 \\
\hline \multirow{4}{*}{$\begin{array}{l}\text { Second } \\
\text { season }\end{array}$} & 0.0 & 1.339 & 5.821 & 4.713 & Second & 0.0 & 1.969 & 4.374 & 5.531 \\
\hline & 30.0 & 6.886 & 10.87 & 9.416 & season & 30.0 & 7.863 & 9.209 & 10.10 \\
\hline & 45.0 & 9.867 & 15.06 & 13.35 & & 45.0 & 10.89 & 12.23 & 15.15 \\
\hline & 60.0 & 9.970 & 14.89 & 13.68 & & 60.0 & 12.87 & 13.53 & 12.14 \\
\hline
\end{tabular}


Table (10 - c) the interaction between BxC

\begin{tabular}{|c|c|c|c|c|c|c|c|c|c|}
\hline \multirow{3}{*}{\begin{tabular}{|l|} 
Organic \\
manure source \\
"B"
\end{tabular}} & \multicolumn{9}{|c|}{ Applied inoculate "C" } \\
\hline & \multicolumn{4}{|c|}{ First season } & \multicolumn{5}{|c|}{ Second season } \\
\hline & 0.0 & \multicolumn{2}{|c|}{ T16 } & T26 & 0.0 & \multicolumn{2}{|c|}{ T16 } & \multicolumn{2}{|c|}{ T26 } \\
\hline \multirow{3}{*}{$\begin{array}{l}0.0 \\
\text { Chicken } \\
\text { Sheep }\end{array}$} & 6.707 & 7.4 & & 8.289 & 6.077 & \multicolumn{2}{|c|}{7.153} & \multirow{2}{*}{\multicolumn{2}{|c|}{7.815}} \\
\hline & 1102 & 128 & & 1368 & 10.17 & \multicolumn{2}{|c|}{11.96} & & \\
\hline & 9.436 & 11. & & 12.23 & 8.949 & 10 & & \multicolumn{2}{|c|}{$\begin{array}{l}12.86 \\
11.52\end{array}$} \\
\hline \multirow{3}{*}{ L. S. D. at 5} & & & A & B & $\mathbf{C}$ & AxB & AxC & BxC & AxBxC \\
\hline & st seaso & & 0.171 & 0.131 & 0.132 & 0.257 & 0.274 & 0.221 & 0.445 \\
\hline & cond se & son & 0.125 & 0.101 & 0.102 & 0.209 & 0.231 & 0.190 & 0.392 \\
\hline
\end{tabular}

\section{3-1 $\mathrm{NO}_{3}$ concentration ( $\mathrm{mg} / \mathrm{kg}$ plant) :-}

Data presented in Tables $(11,11 a, b \& c)$ indicate that $\mathrm{NO}_{3}$ concentration (mg / kg plant) was significantly increased with application of chemical $\mathrm{N}$ rates, organic manures or biofertilizers. Among the various chemical $\mathrm{N}$ rates, application of $60 \mathrm{~kg} \mathrm{~N} /$ fed., showed the highest values (433.44 and $489.44 \mathrm{mg} / \mathrm{kg}$ plant), whereas chicken manure surpassed sheep manure in this character (285.6and 317.08 versus 270.92 and 301.92 $\mathrm{mg} / \mathrm{kg}$ plant), for the first and second seasons respectively. Meanwhile insignificant difference were obtained between T26 and T16 ( 310.25 versus $304.17 \mathrm{mg} / \mathrm{kg}$ plant) for the first season. It should be mentioned that biofertilizers inoculation showed the lowest values followed by organic manures and $\mathrm{N}$-chemical application showed the highest values in this character. Increasing $\mathrm{NO}_{3}$ concentrations with increasing $\mathrm{N}$-fertilizer rates agreed with that obtained on some vegetables as reported by Maynared et al. (1976); Gardner and Pew (1979); and on potato by Willumsen (1984) and disagreed with Steenhuizen (1986) and Blom-Zandstra (1989); and Mazur (1992) on squash. Application of organic manure increased $\mathrm{NO}_{3}$, which disagreed with that obtained on tomato by Yamada and Kamata (1989).

Regarding the interactions between $\mathrm{A} \times \mathrm{B}$, significant increase in $\mathrm{NO}_{3}$ ( $\mathrm{mg} / \mathrm{kg}$ plant) were obtained, in both seasons. The highest values were observed from the application of $60 \mathrm{~kg} \mathrm{~N} /$ fed., $\mathrm{x}$ chicken manure (450.0 and $504.0 \mathrm{mg} / \mathrm{kg}$ plant).

Concerning the interactions between $\mathrm{A} \times \mathrm{C}$, significant increase in this character was gained, in both seasons. Application of $60 \mathrm{~kg} \mathrm{~N} /$ fed., $x$ T26 gave the highest value. Significant increase was obtained from the interaction between $\mathrm{B} \times \mathrm{C}$, in both seasons. $\mathrm{NO}_{3} \mathrm{mg} / \mathrm{kg}$ plant from the interaction of chicken manure $\times$ T26 showed the highest values (295.00 and $325.25 \mathrm{mg} / \mathrm{kg}$ plant).

In general, the interaction of $A \times B \times C$ showed significant effect, in both season. Among these interactions, the highest values of NO3 mg / kg plant were obtained from chemical $\mathrm{N}$ at $60 \mathrm{~kg} / \mathrm{fed}$., $\mathrm{x}$ chicken manure $\mathrm{x}$ T26. 3-2 - $\mathrm{NO}_{2}$ concentration ( $\mathrm{mg} / \mathrm{kg}$ plant): -

Data in Tables $(12,12 \mathrm{a}, \mathrm{b} \& \mathrm{c})$ showed that NO2 $\mathrm{mg} / \mathrm{kg}$ plant were significantly increased with application of chemical $\mathrm{N}$ rates, organic manures or inoculation with T16 and T26, in both seasons. Among the various chemical $\mathrm{N}$ rates, application of $60 \mathrm{~kg} \mathrm{~N} /$ fed., showed the highest values (4.75 and $5.446 \mathrm{mg} / \mathrm{kg}$ plant), whereas chicken manure surpassed sheep 
Hassan, E. A. et al.

manure in this character $(3.092$ and 3.542 versus 2.958 and $3.387 \mathrm{mg} / \mathrm{kg}$ plant). On the contrarily, insignificant difference were obtained between T16 and T26 in this character. The results indicated that biofertilizer treatments showed the lowest values as compared with either chemical $\mathrm{N}$-rates or organic manures and the latter is ranked as an intermediate.

In general, the interactions between $A \times B$ showed significant increase in this character, in both seasons. The highest values were observed from the application of $60 \mathrm{~kg} \mathrm{~N} / \mathrm{fed}, \mathrm{x}$ chicken manure $(4.87$ and $5.533 \mathrm{mg} / \mathrm{kg}$ plant). Regarding, the interactions between $\mathrm{A} \times \mathrm{C}$ significant increase in this character were obtained. Application of $60 \mathrm{~kg} \mathrm{~N} /$ fed., x T26 showed the highest values $(4.86$ and $5.51 \mathrm{mg} / \mathrm{kg}$ plant) for the first and second seasons, respectively. Concerning the interaction between $\mathrm{B} \times \mathrm{C}$ significant increase in $\mathrm{NO}_{2}$ / plant were gained, in both seasons. $\mathrm{NO} 2 \mathrm{mg} / \mathrm{kg}$ plant from the interaction of chicken manure $\times$ T26 showed the highest values (3.163 and $3.610 \mathrm{mg} / \mathrm{kg}$ plant) for the first and second seasons, respectively.

Table (11): Effects of $\mathbf{N}$ - chemical rates / fed., organic manure source or / and biofertilizer inoculums on $\mathrm{NO}_{3}$ concentration $(\mathrm{mg} / \mathrm{kg}$ plant) of squash plants during the two autumn seasons.

\begin{tabular}{|c|c|c|c|c|c|c|c|c|c|c|c|c|c|}
\hline \multirow{5}{*}{$\begin{array}{l}\text { Organic } \\
\text { source } \\
\text { "B"B" }\end{array}$} & \multicolumn{13}{|c|}{ First season } \\
\hline & \multicolumn{12}{|c|}{ Chemical N- rates / fed. "A" } & \multirow{4}{*}{$\begin{array}{c}\text { Mean } \\
\text { "B" }\end{array}$} \\
\hline & \multicolumn{3}{|c|}{$0.0 \mathrm{~kg}$} & \multicolumn{3}{|c|}{$30.0 \mathrm{~kg}$} & \multicolumn{3}{|c|}{$45.0 \mathrm{~kg}$} & \multicolumn{3}{|c|}{$60.0 \mathrm{~kg}$} & \\
\hline & \multicolumn{12}{|c|}{ Applied inoculate "C" } & \\
\hline & 0.0 & $T_{16}$ & $\mathbf{T}_{26}$ & 0.0 & $T_{16}$ & $\mathbf{T}_{26}$ & 0.0 & $\mathbf{T}_{16}$ & $\mathbf{T}_{26}$ & 0.0 & $T_{16}$ & $\mathbf{T}_{26}$ & \\
\hline 0.0 & 77.00 & 85.0 & 90.0 & 202.0 & 211.0 & 218.0 & 295.0 & 311.0 & 318.0 & 405.0 & 418.0 & 430.0 & 255.0 \\
\hline Chicken & 100.0 & 110.0 & 113.0 & 230.0 & 245.0 & 253.0 & 325.0 & 346.0 & 355.0 & 439.0 & 451.0 & 460.0 & 285.6 \\
\hline She & 92.00 & 104.0 & 108.0 & 215.0 & 225.0 & 231.0 & 312.0 & 327.0 & 339.0 & 422.0 & 434.0 & 442.0 & 270.9 \\
\hline Mean"A" & & 97.67 & & & 225.56 & & \multicolumn{3}{|c|}{325.33} & \multicolumn{4}{|c|}{433.44} \\
\hline Mean"C" & \multicolumn{6}{|c|}{0.0 untreated $=259.5$} & & $16=272$ & 2.3 & & $\mathrm{~T}_{26}=$ & $=279.8$ & \\
\hline \multicolumn{14}{|c|}{ Second season } \\
\hline 0.0 & 85.00 & 95.00 & 100.0 & 242.0 & 252.0 & 260.0 & 330.0 & 341.0 & 347.0 & 460.0 & 472.0 & 481.0 & 288.75 \\
\hline Chicken & 120.0 & 132.0 & 136.0 & 271.0 & 283.0 & 290.0 & 345.0 & 356.0 & 360.0 & 492.0 & 505.0 & 515.0 & 317.08 \\
\hline Sheep & 98.0 & 107.0 & 112.0 & 256.0 & 264.0 & 268.0 & 339.0 & 347.0 & 352.0 & 482.0 & 496.0 & 502.0 & 301.92 \\
\hline Mean "A & \multirow{2}{*}{\multicolumn{6}{|c|}{\begin{tabular}{c|c}
109.44 & 295.11 \\
0.0 untreated $=293.333$ \\
\end{tabular}}} & \multirow{2}{*}{\multicolumn{3}{|c|}{$\frac{346.333}{T_{16}=304.1}$}} & \multicolumn{4}{|c|}{489.44} \\
\hline Mean "C & & & & & & & & & & & $\mathrm{T}_{26}=$ & 310.2 & \\
\hline
\end{tabular}

Table (11 - a) the interaction between AxB Table(11 - b) the interaction between AxC

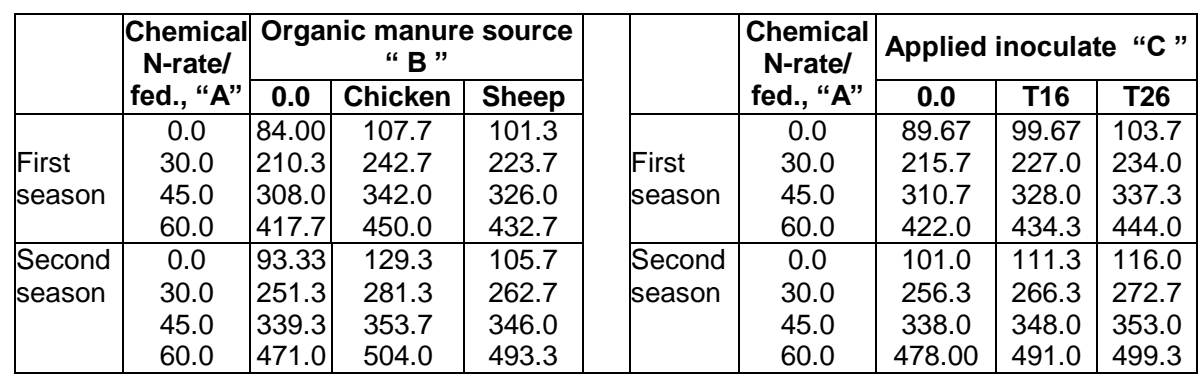


Table (11- c) the interaction between BxC

\begin{tabular}{|c|c|c|c|c|c|c|c|c|c|}
\hline \multirow{3}{*}{$\begin{array}{l}\text { Organic } \\
\text { manure source } \\
\text { "B" }\end{array}$} & \multicolumn{9}{|c|}{ Applied inoculate "C" } \\
\hline & \multicolumn{4}{|c|}{ First season } & \multicolumn{5}{|c|}{ Second season } \\
\hline & 0.0 & \multicolumn{2}{|c|}{ T16 } & T26 & 0.0 & \multicolumn{2}{|c|}{ T16 } & \multicolumn{2}{|c|}{ T26 } \\
\hline & 244.8 & 256 & & 264.0 & 279.25 & \multicolumn{2}{|c|}{290.00} & \multicolumn{2}{|c|}{297.00} \\
\hline Chicken & 273.5 & 288 & & 295.3 & 307.00 & \multirow{2}{*}{\multicolumn{2}{|c|}{$\begin{array}{l}319.00 \\
303.50\end{array}$}} & \multirow{2}{*}{\multicolumn{2}{|c|}{325.25}} \\
\hline Sheep & 260.3 & 272 & & 280.0 & 293.75 & & & & \\
\hline \multirow{3}{*}{ L. S. D. at } & & & $\mathbf{A}$ & B & $\mathbf{C}$ & AxB & AxC & BxC & AxBxC \\
\hline & rst seas & & 9.36 & 8.49 & 7.88 & 16.98 & 15.75 & 13.64 & 27.28 \\
\hline & econd $\mathrm{se}$ & ason & 2.18 & 1.90 & 2.36 & 3.79 & 4.71 & 4.08 & 8.16 \\
\hline
\end{tabular}

Table (12): Effects of $\mathbf{N}$ - chemical rates / fed., organic manure source or / and biofertilizer inoculums on $\mathrm{NO}_{2}$ concentration $(\mathrm{mg} / \mathrm{kg}$ plant)of squash plants during the two autumn seasons.

\begin{tabular}{|c|c|c|c|c|c|c|c|c|c|c|c|c|c|}
\hline \multirow{5}{*}{$\begin{array}{l}\text { Organic } \\
\text { source } \\
\text { "B" }\end{array}$} & \multicolumn{13}{|c|}{ First season } \\
\hline & \multicolumn{12}{|c|}{ Chemical N- rates / fed. "A" } & \multirow{4}{*}{$\begin{array}{c}\text { Mean } \\
\text { "B" }\end{array}$} \\
\hline & \multirow{2}{*}{\multicolumn{3}{|c|}{$0.0 \mathrm{~kg}$}} & \multicolumn{3}{|c|}{$30.0 \mathrm{~kg}$} & \multicolumn{3}{|c|}{$45.0 \mathrm{~kg}$} & \multirow{2}{*}{\multicolumn{3}{|c|}{$60.0 \mathrm{~kg}$}} & \\
\hline & & & & \multicolumn{6}{|c|}{ Applied inoculate "C" } & & & & \\
\hline & 0.0 & $T_{16}$ & $T_{26}$ & 0.0 & $T_{16}$ & $T_{26}$ & 0.0 & $T_{16}$ & $T_{26}$ & 0.0 & $T_{16}$ & $T_{26}$ & \\
\hline 0.0 & 0.630 & 0.720 & 0.76 & 2.470 & 2.600 & 2.650 & 3.450 & 3.600 & 3.700 & 4.500 & 4.700 & 4.800 & 2.882 \\
\hline Chicken & 0.860 & 0.990 & 1.02 & 2.690 & 2.740 & 2.810 & 3.710 & 3.800 & 3.860 & 4.760 & 4.900 & 4.960 & 3.092 \\
\hline Sheep & 0.750 & 0.810 & 0.86 & 2.580 & 2.640 & 2.700 & 3.850 & 3.690 & 3.750 & 4.610 & 4.720 & 4.810 & 2.958 \\
\hline Mean"A" & & 0.8220 & & & 2.650 & & & 3.680 & & \multicolumn{4}{|c|}{4.750} \\
\hline Mean"C" & \multicolumn{6}{|c|}{0.0 untreated $=2.883$} & \multicolumn{3}{|c|}{$\mathrm{T}_{16}=2.993$} & & $T_{26}=$ & 3.057 & \\
\hline \multicolumn{14}{|c|}{ Second season } \\
\hline .0 & 0.670 & 0.780 & 0.830 & 2.77 & 2.900 & 2.940 & 4.080 & 4.170 & 4.240 & 5.250 & 5.340 & 5.400 & 3.281 \\
\hline Chicl & 1.080 & 1.150 & 1.200 & 3.05 & 3.150 & 3.200 & 2.260 & 4.370 & 4.450 & 5.460 & 5.550 & 5.590 & 3.542 \\
\hline Sheep & 0.810 & 0.860 & 0.890 & 2.92 & 3.500 & 3.050 & 4.150 & 4.240 & 4.300 & 5.390 & 5.490 & 5.540 & 3.387 \\
\hline Mean "A & \multirow{2}{*}{\multicolumn{3}{|c|}{.9190}} & \multirow{2}{*}{\multicolumn{3}{|c|}{$\frac{2.998}{3.324}$}} & \multirow{2}{*}{\multicolumn{3}{|c|}{$\frac{4.251}{16=3.417}$}} & \multicolumn{4}{|c|}{5.446} \\
\hline Mean "C & & & & & & & & & & & $T_{26}=$ & 3.469 & \\
\hline
\end{tabular}

\section{Table (12-a) the interaction between AxB Table(12-b) the interaction between AxC}

\begin{tabular}{|c|c|c|c|c|c|c|c|c|c|}
\hline & \multirow{2}{*}{$\begin{array}{c}\text { Chemical } \\
\text { N-rate/ } \\
\text { fed., "A" }\end{array}$} & \multicolumn{3}{|c|}{\begin{tabular}{|c|} 
Organic manure source \\
"B "
\end{tabular}} & & \multirow{2}{*}{\begin{tabular}{|c|} 
Chemical \\
N-rate/ \\
fed., "A" \\
\end{tabular}} & \multicolumn{3}{|c|}{ Applied inoculate " $C$ " } \\
\hline & & 0.0 & Chicken & Sheep & & & 0.0 & T16 & T26 \\
\hline \multirow{4}{*}{$\begin{array}{l}\text { First } \\
\text { season }\end{array}$} & 0.0 & 0.703 & 0.957 & 0.807 & \multirow{4}{*}{$\begin{array}{l}\text { First } \\
\text { season }\end{array}$} & 0.0 & 0.747 & 0.840 & 0.880 \\
\hline & 30.0 & 2.570 & 2.750 & 2.640 & & 30.0 & 2.580 & 2.660 & 2.720 \\
\hline & 45.0 & 3.580 & 3.790 & 3.670 & & 45.0 & 3.580 & 3.690 & 3.770 \\
\hline & 60.0 & 4.670 & 4.870 & 4.710 & & 60.0 & 4.620 & 4.770 & 4.860 \\
\hline \multirow{4}{*}{$\begin{array}{l}\text { Second } \\
\text { season }\end{array}$} & 0.0 & 0.760 & 1.143 & 0.853 & \multirow{4}{*}{$\begin{array}{l}\text { Second } \\
\text { season }\end{array}$} & 0.0 & 0.853 & 0.930 & 0.973 \\
\hline & 30.0 & 2.870 & 3.133 & 2.990 & & 30.0 & 2.913 & 3.017 & 3.063 \\
\hline & 45.0 & 4.163 & 4.360 & 4.230 & & 45.0 & 4.163 & 4.260 & 4.330 \\
\hline & 60.0 & 5.330 & 5.533 & 5.473 & & 60.0 & 5.367 & 5.460 & 5.510 \\
\hline
\end{tabular}

Table (12 - c) the interaction between BxC

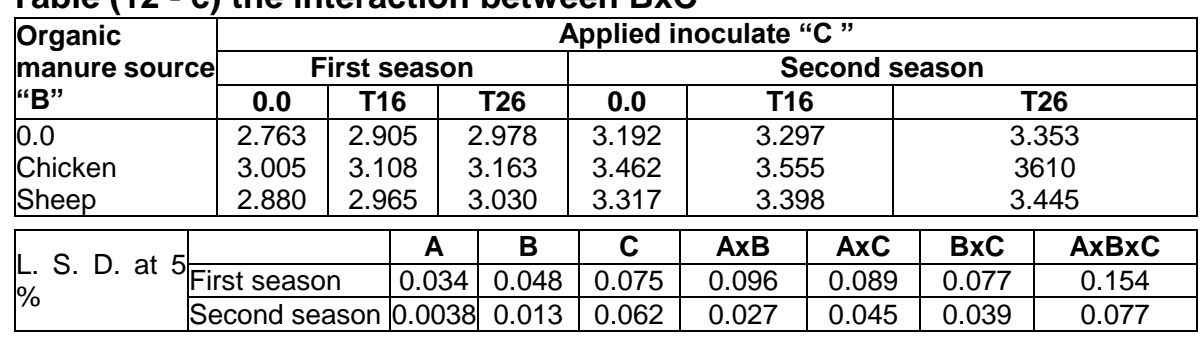


Hassan, E. A. et al.

The interactions of the three factors resulted on significant effect, in both seasons. Among these interactions, the highest values of $\mathrm{NO}_{2} \mathrm{mg} / \mathrm{kg}$ plant were obtained from chemical $\mathrm{N}$ at $60 \mathrm{~kg} \mathrm{~N} /$ fed., $\mathrm{x}$ chicken manure $\mathrm{x}$ T26 i.e.; 4.96 and 5.59 for the first and second seasons, respectively.

From the previous results in these investigations, it seemed to be that application of chemical-N showed greatest number of leaves and leaf area per plant reflected in the highest early and total yield than that obtained from organic manures or bio-fertilizers treatments. This may be due to the quickest and most pronounced effect of commercial chemical- $\mathrm{N}$, which tends to encourage aboveground vegetative growth through its role in the formation of proteins and as a part of the chlorophyll molecule. On the other hand, both $\mathrm{NO}_{3}$ and $\mathrm{NO}_{2}$ concentrations had increased markedly with increasing chemical $\mathrm{N}$-rates in the tissues of squash plants. Therefore, it can be suggested that under chemical- $\mathrm{N}$ fertilizers application, plants may absorb great quantity of $\mathrm{N}$ than its assimilation capacity and the unutilized $\mathrm{N}$ will be stored as $\mathrm{NO}_{3}$ in plant tissues. Nitrate accumulations in edible plant is considered hazardous to human health. Craddock (1983) pointed out that $\mathrm{NO}_{3}$ may harm the health of the consumer as it can be converted to $\mathrm{NO}_{2}$. This $\mathrm{NO}_{2}$ oxidizes iron in hemoglobin from active ferrous form to the ferric state yielding methemoglobin, which cannot transport $\mathrm{O}_{2}$.

Application of organic manure particularly chicken manure produced the earlienest appearance of the first female flower as well as the lowest sex ratio. The results showed that organic manures produced the earliest female flower; this may be attributed to higher $\mathrm{N}$ and $\mathrm{P}$ element in chicken manure and sheep manures. Whereas, the low NO3 and NO2 percentage in squash plant tissues may be due to high $\mathrm{NH} 2$ and $\mathrm{NH} 4$ contents in organic manures which need sometime to be converted to NO3 after nitrification. Gardner and Pew (1979) suggested that the slower nitrification rate with the sources containing NH4-N was considered to be the cause for the initially lower NO3$\mathrm{N}$ level, Gobal (1980) pointed out that the lowest values of NO3-N in plants supplied with $\mathrm{NH} 4-\mathrm{N}$ sources may be due to $\mathrm{NH} 4$ which is used directly in $\mathrm{N}$ assimilation in plant tissues, however, $\mathrm{NO} 3$ must be reduced at first to $\mathrm{NH} 4$ by nitrate reeducates enzymes in plants.

Bio-fertilizer has stimulated considerable attention and interest in recent years for its potential and ability to fix $\mathrm{N}$ and produce of phytohormon. Treatments with bio-fertilizer resulted in the tallest squash plants with highest number of internodes per plant. This may be due the efficiency of biofertilizers in improving soil fertility and secretion of growth substance (IAA and $\mathrm{GA}$ ) and antifungal chemicals as well as improving seed germination and root growth, thus, increasing agricultural production. Among the various interactions an additive positive effect on yield and its components were observed. Marked increase in these parameters were obtained particularly early and total yield from the triple interaction i.e.; application of $45 \mathrm{~kg} \mathrm{~N} / \mathrm{fed}$. $x$ chicken manure ( 7.5 ton/fed.) x T26. It could be concluded that the primary problem with single application of organic manure or biofertilizers is the low yield procured, when compared to that of conventional chemical-N fertilizer system. However, the interaction of chicken manure x T26 resulted in total yield / fed. and average fruit weight with lowest NO3 and NO2 as compared 
with single application $\mathrm{kg} \mathrm{N} / \mathrm{fed}$. This is principally observed in the obtained results. Hence, the promotion and development of organic systems must be coupled with technologies that would enhance yields while preserving and possibly improving the sustainability of the systems also the environment. Therefore, further studies are needed.

\section{REFERENCES}

${ }^{*}$ Abd-El-Fattah , M.A. and Mervat E. Sorial (2000): Sex Expression and productivity responses of summer squash to biofertilizer application under different nitrogen levels . Zagazig , J. Agric. Res. 27 (2) : 255:281 .

Abd El-Rahem, A.T.;R.A.Ragub;O.F.Dakhly and R.A.Eid (1995): Improvement of Azotobacter vinelandii efficiency for nitrogen fixation through mutation induction and conjugation. Egypt J. Appli. Sci.,10(8):753-771.

Abo-Hussein, S.D. (1995): Studies on potato fertigatuio in newly reclaimed land. M. Sc. thesis, fac. of Agric., Ain Shams Univ. 164 pp.

Alexiev, N. and Rankov V. (1997): The effect of intensive orangomineral fertilizers on the yield of tomatoes grown in plastic greenhouses, and on biological soil activity . Acta Horticulturae No. 462, 687 - 692 .

Ali, F.A. and A.H. Selim (1996): Response of tomato ( Lycopersicon esculentum L. " Castle Rock ") to inoculation with Azotobacter and different levels of phosphorus and potassium fertilization. Menofiya $\mathrm{J}$. Agric. Res., 21 (4) : 795 - 817.

Alphonse, M. and Saad, E.M. (2000a): Effect of some organic media and micronutrients on mineral contents of plastichouse Cucumber. Egypt. J. Hort. 27 , No. 3 pp. 385 - 408 .

Alphonse, M. and Saad, E.M. (2000b): Growing greenhouse Cucumber in farmyard and chicken manure media in combination with foliar application of zinc, manganese and boron . Egypt. J. Hort.27, No. pp. $315-336$.

A.O.A.C. (1990): "Official of analysis ", 15 th ed., Association of official analytical Chemists, Washington, D.C.

Ashour, S.A.; A.E. Abd-El-Fattah and A.A. Tawfik (1997): Effect of nitrogen (biofertilizer) and different levels of nitrogen growth and yield of potato (Solanum tuberosum , L. ) J. Agric. Sci., Mansoura Univ. 22 (11) 3979 3986 .

Barakat, M.A.S. and S.M. Gabr (1998): Effect of different biofertilizer types and nitrogen fertilizer levels on tomato plants. Alex. J. Agric. Res. 43 (1) : 149 - 160 .

Blom - Zandstra ,M. (1989): Nitrate accumulation in vegetables and its relationship to quality. Ann appl. Biol. $115: 553-561$.

Buwalda , J.G. and Freeman, R.E. (1986): Melons:effects of vine pruning and nitrogen on yields and quality .New Zealand Journal of Experimental Agreculture 355 - 359 . ( C.F. Hort. Abst. vol. $57: 3375$ ). 
Hassan, E. A. et al.

Craddock, V.M. (1983): Nitrosamines and human cancer : Proof of an association Nature 306 - 638 .

Dakhly, O.F. (1993): Symbiotic efficiency of salt tolerant transformants of two Rhizobin species. Egypt. J. Genet. Cytol., 22 : 131 - 144 .

Dakhly, O.F. and Abd EL- Mageed Y.T. (1997): Estimation of effectiveness of Azotobacter chroococcum transformants on growth and yield of some vegetable crops . Egypt. J. Genet. Cytol., $26: 73-88$.

Das, R.C. and Swain, S.C. ( 1977 ): effect of growth substances and nitrogen on the growth, yield and quality of pumpkin ( Cucurbita moschata Duchene ) . Indian Journal Horticulture (1977) 34(1) 51 - 55 (En, 7 ref. Orissa University of Agriculture and Technology, Bhubaneswar, India (C.F. Hort. Abst. $48: 2337$ ) .

El - Mansi, A. A. A., Bardisi, H.M. E. Arisha and E.M. Nour (1999): Studies on some factors affecting growth and yield of pea under sandy soil conditions using drip irrigation system -2- Effect of farmyard manure and irrigation water quantity . Zagazig J. Agric. Res., 26 (5) : 1409 - 1428.

El- Qassas, H.I., A.f. Abou Hadid, and N.M.H. Eisa (1997): Effect of different organic manures on the yield and elemental composition of sweet pepper plants grown on sandy soil . Egypt. J. Appl. Sci., 12 (3) : $262-281$.

FAO (2001): Bulletin of Statistics Vol. 2 No.(2): 144 .

Fatma H. El- Ghinbihi and Fetouh A.Ali ( 2001 ): Response of some potato cultivars to biofertilizer ( Halex 2 ) and defferent mineral nitrogen levels . Zagazig J. Agric. Res., vol. 28, No. (1).

Fayez M.F., (1981): Studies on the associative symbiosis between $\mathrm{N}$ - fixing bacteria and wheat 2 (Triticum aestivum) under semi and temperate conditions. Ph. D. Thesis, Faculty of Agronomy, Katholeike Universiteit Leuven, Belgium.

Feleafel , M.N. (2000): Effect of nitrogen and potassium fertilization on growth , flowering and yield of pumpkin (Cucurbita pepo L.) . J. Agric. Sci. Mansoura Univ., 25 (11) : 6781 - 6791.

Ganeshe, R.K.; R.P. Pandey and A.K. Rawat (1998): Comparative performance of biofertilizers and chemical nitrogen on the yield of okra . Hort. J. 11(2): 53 - 58 ( C. F. Hort. Abst., 69 (5) : 4097 ) .

Gardner, B.R. and Pew. W.D. (1979): Comparison of various nitrogen sources for the fertilization of winter-grown head lettuce. J. Amer. Soc. Hort. Sci. 104 (4) : 534 - 536.

Gobal , M.R. (1980):Studies on the response of poprika varieties to nitrogen level and forms under different environmental conditions. Ph. D. thesis , Budapest , Hungary .

Gomes,K. A. and A. A. Gomes (1984): Statically procedures of agricultural research. John Willy \& sons, New York.

Gardner , B.R. and Pew . W.D. (1979): Comparison of various nitrogen sources for the fertilization of winter grown head lettuce . J. Amer. Sci. 104 (4) : 534- 536.

Hassan E.A.; O.F.Dakhly and F.A.S.Nassif (2000): Increasing yield of Squash plant through inoculation by mutants and hybrids of two Azotobacter 
species. Proceed 2nd Arab Cong. Genet. Biotech. (Oct. 23-26, 2000): $131-150$.

Hilal, M.H. and Selim , A.M.(1992): Enhancing and retarding effects of combined sulphur and fertilizer applications on crop production in different soils . Proceedings Midle East Sulphur Symposium , 281 - 289 ; 6 ref.. ( CAB Abst. 1992).

Huett, D.O. (1986): Response to nitrogen and potassium of tomatoes growen in sand soil . Aust. J. Exp. Agric. 26, 133 - 138 .

Huett, D.O. and Dettmann E.B. (1988): Effect of nitrogen on growth, fruit quality and nutrient uptake of tomatoes grown in sand culture. Aust. J. $\quad$ Exp. Ageic. 28, $391-409$.

Ibrahim M. Ghoneim and Aly H. Abdel - Razik (1999): Effect of biofertilization under different nitrogen levels on growth, yield and chemical contents of potato plants . Adv. Agric. Res. vol. 4, $757-769$.

Jadhav, A.C., S.A. Memane and B.K. Konde (1998): Evaluation of biofertilizers in respect to growth and yield attributing parameters in sweet potato . J. of Maharashtra Agric. Univ., 23 (1) : 80 - 82 .

Maynared, D.N. and Barker, A. V.; Minotti , P. L. and Peck, N. H. (1976): Nitrate accumulation in vegetables. Advances in Agronomy 28: 70 118.

Maynard, A. A. (1989): Protecing Groundwater while recycling nutrients . BioCyele 35 (5): 40 ( C. F. Hort. Abst. vol. 65 : 2954 ) .

Mazur - Z. (1992): Effect of nitrogen fertilization on the contents on the nitrates and nitrites in vegetables. Biuletyn - Warzywniczy . 1992, 38: 132 - 139; 18 ref.. (CAB Abst. 1993 - 1994).

Page, A.L. (1982): " Methods of Soil Analysis ". Part2. Chemical and microbiological properties ( 2 nd ed.). Agron. 9,Am. Soc. Agron. Inc. Publ., Madison, Wis. USA.

Pandey, A. and S. Kumar (1989): Potential of Azotobacters and Azospirilla as biofertilizers for upland agriculture. J. of Indust. Res., 48 (3): $134 \quad$ 144.

Pelaez , R.J.; (1984): Response of squash (Cucurbita pepo L.) to fertilization with nitrogen, phosphorus, potassium and organic matter. Acta Agronomica 86 - 95. (C. F. Hort. Abst. Vol. 55: 9519).

Rajendran, P.C., (1983): Effects of graded doses of nitrogen, phosphorus and potassium on yield of pumpkin ( Cucurbita moschata Poir) . agricultural Research of Kerala 51-54 . ( C. F. Hort. Abst. Vol. $55: 9520$ )

Reiners, S. and D. I. M. Riggs. (1997): Plant spacing and variety affect pumpkin yield and fruit size but supplemental nitrogen does not. Hortsci.32(6):1037- 1039.

Rovira, A.D. (1963): Microbial inoculation of plants. I. Establishment of freeliving nitrogenfixing bacteria in the rhizosphere and their effects on maize, tomato and wheat . Plant and soil, 10 (3) : 304 - 314 .

Segura, M.L. (1999): Organic manures in intensive horticultural. Horticultura, Revista de frutas,. Hortslizas, Flores, Plantas. Ornamentales - y Plantas - de - Vivero. 1999, No. 138, $17-20 ; 10$ ref. ( CAB Abst. 1998 / 2000 / 01) . 
Hassan, E. A. et al.

Shahaby, A.F.; Amin. G. and Khalafalla, G. M. (1993): Response of rice and tomato seedlings to inoculation with diazotrophs and their culture filtrates. 6th. Inter. Symp. on Nitrogen fixation with Non.- Legumes Ismailia. Egypt, 6 - 10 Sept.; 375 - 376.

Sidorenko, O.; V. Storozhenko and O. Kukharenkova (1996): The use of bacterial preparations in potato cultivatio .Mezhdunarodnyisel'skokhozy-aistvennyi-Zhurnal . No. 6, 36 - 38 .

Steenhuizen, J.W. (1986): Nitrate content of lettuce on nutrient film. 4. Ammonium / nitrate. External quality as affected by 15, 12, 8 and 4 days before harvest. Rapport. Institut. Voor. Bodemvruchtbarrheid No. 6, 85 pp. (Cited fram Hort. Abst. 1988 Vol. 58 No. 7,4139 ) .

Swiader , J.M., J,M., J.G. Sullivan, f.g. Freiji and J.A. Grunau. (1988): Nitrate monitoring for Pumpkin production on dry land irrigated soil-. J. Amer. Soc. Hort. Sci. 113: $684-689$.

Vennxi, G. and R. Piazza (1975): The effects of nitrogen, phosphorus and potassium on summer squash, Cucurbita pepo L. Rivista di. Agronomica 7(2/3), 143- 149. Universita di. Bologno, Italy (C.F. Hort. Abstr. 1974,44(8): 5656.

Wagih R.R.; (1986): Effect of plant spacing and nitrogen levels on some economic characters of squash . Bull. Fact. of Agric. , Univ. of Cairo, Vol. 37 , No. 1: 33 - 364 .

Wange, S.S. (1996): Response of garlic to combined application of biofertilizers and nitrogen fertilizer. J. of Soils and Crops, 5 (2) : 115 116 .

Warade, S.D., S. B. Desale and K. G. Shinde (1995): Effect of organic, inorganic and biofertilizers on yield of onion bulbs Cv. B- 780. J. of Maharashtra Agri. Univ. 20 (3) 467 - 468.

Warman, P.R. and K. A. Harvard (1996): Yield, vitamin and mineral content of four vegetables grown with either compost manure or conventional fertilizer. J. of Vegetable Crop Production., 2 (1) : 13 25

Willumsen, J.(1984): Nutritional requirements of lettuce in water culture . Proceeding of the International Society of Soilles Culture, PP 777 - 791

Yamada, H. and Kamata (1989): Agricultural technological evaluation of vegetables and soil physical and chemical properties. Bulletin of the agricultural Research Institute of Kanagawa Prefecture No. 131, 1 - 13 (C. F. Hort. Abst. vol. 59: 8215). 
تأثير المصادر المختلفة للنيتروجين على الإزهار والمحصول وجودة الثمـار لنباتات

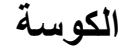

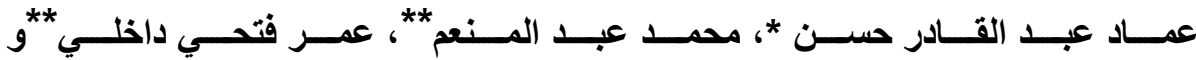

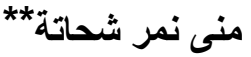

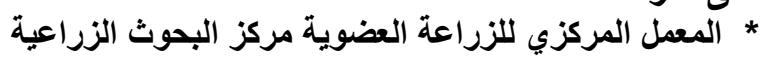

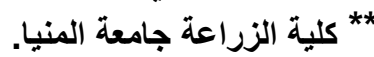

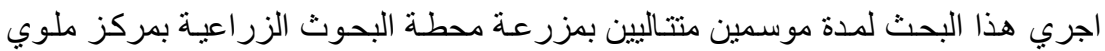

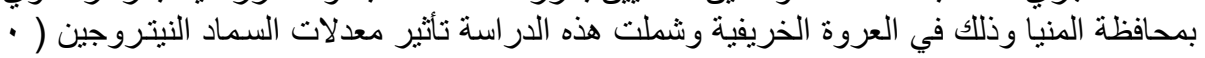

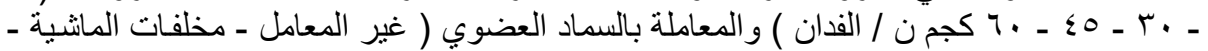

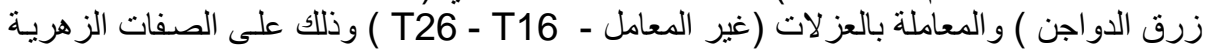

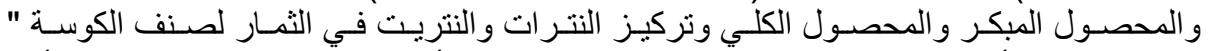

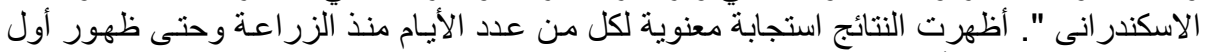

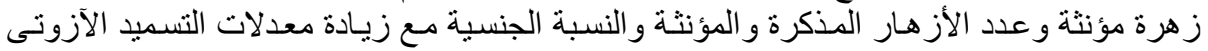

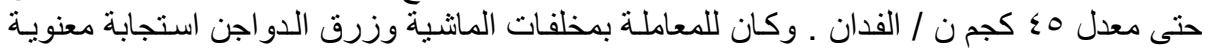

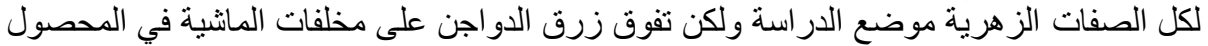

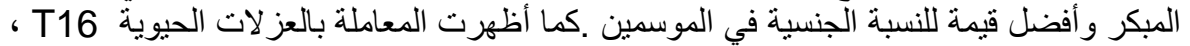

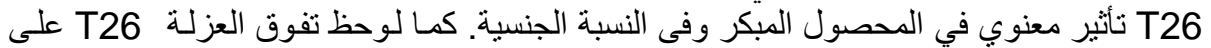

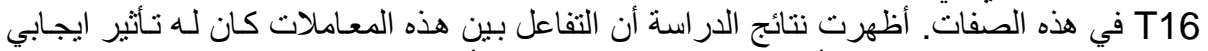

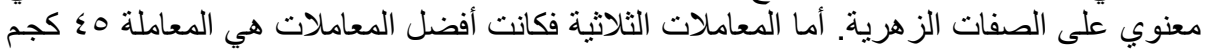
ن / الفدان + زرق الدواجن + T26 في كلا الموسمين .

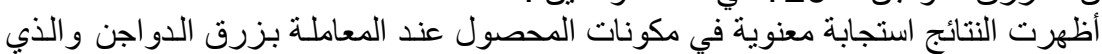

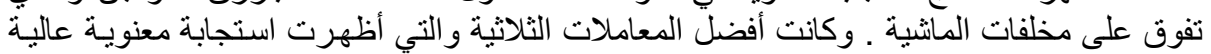

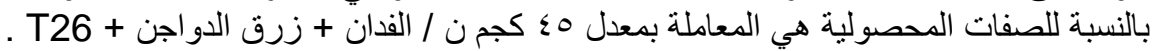

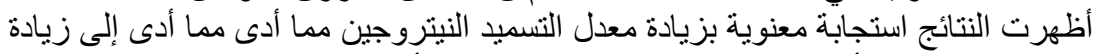

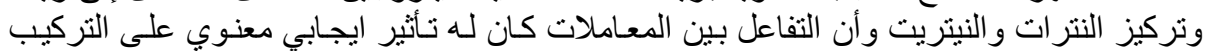

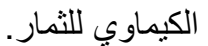

